\title{
Coeliac disease: a diverse clinical syndrome caused by intolerance of wheat, barley and rye
}

\author{
Norma McGough $^{1}$ and John H. Cummings ${ }^{2 *}$ \\ ${ }^{1}$ Coeliac UK, Suite A-D, Octagon Court, High Wycombe, Bucks. HP11 2HS, UK \\ ${ }^{2}$ Division of Pathology and Neuroscience, University of Dundee, Ninewells Hospital and Medical School, \\ Dundee DDI 9SY, UK
}

\begin{abstract}
Coeliac disease is a lifelong intolerance to the gluten found in wheat, barley and rye, and some patients are also sensitive to oats. The disease is genetically determined, with $10 \%$ of the first-degree relatives affected and $75 \%$ of monozygotic twins being concordant. Of the patients with coeliac disease 95\% are human leucocyte antigen (HLA)-DQ2 or HLA-DQ8 positive. Characteristically, the jejunal mucosa becomes damaged by a T-cell-mediated autoimmune response that is thought to be initiated by a 33-mer peptide fragment in A2 gliadin, and patients with this disorder have raised levels of anti-endomysium and tissue transglutaminase antibodies in their blood. Coeliac disease is the major diagnosable food intolerance and, with the advent of a simple blood test for case finding, prevalence rates are thought to be approximately $1: 100$. Classically, the condition presented with malabsorption and failure to thrive in infancy, but this picture has now been overtaken by the much more common presentation in adults, usually with non-specific symptoms such as tiredness and anaemia, disturbance in bowel habit or following low-impact bone fractures. Small intestinal biopsy is necessary for diagnosis and shows a characteristically flat appearance with crypt hypoplasia and infiltration of the epithelium with lymphocytes. Diet is the key to management and a gluten-free diet effectively cures the condition. However, this commitment is lifelong and many aisles in the supermarket are effectively closed to individuals with coeliac disease. Compliance can be monitored by measuring antibodies in blood, which revert to negative after 6-9 months. Patients with minor symptoms, who are found incidentally to have coeliac disease, often ask whether it is necessary to adhere to the diet. Current advice is that dietary adherence is necessary to avoid the long-term complications, which are, principally, osteoporosis and small bowel lymphoma. However, risk of these complications diminishes very considerably in patients who are on a gluten-free diet.
\end{abstract}

Coeliac disease: Gluten: Diet

Coeliac disease (CD) is a genetically-determined autoimmune condition that can present at any age and for which there is a clearly-defined pathology and diagnostic test. $\mathrm{CD}$ is a permanent intolerance to the gliadin fraction of proteins in wheat, barley and rye, with some individuals with CD also sensitive to oats. Although primarily manifest as a disorder of the mucosa of the duodenum and jejunum, leading in severe cases to malabsorption, it can present in many ways and is a syndrome with many facets. Increasingly, cases are found as a result of screening blood tests in anaemic patients or in associated conditions such as type 1 diabetes, thyroid disease or from endoscopic biopsies of the duodenum in procedures carried out for unrelated conditions such as dyspepsia or gastrooesophageal reflux disease. This so-called 'silent' $\mathrm{CD}$ is but one aspect of a condition that can include: anaemia; osteoporosis; dermatitis herpetiformis (DH; a skin manifestation of an autoimmune response associated with CD); microscopic colitis; frank malabsorption with weight loss and steatorrhoea; infertility; miscarriage; folate deficiency; malignancy such as lymphoma; rare neurological disorders. CD, and most of its manifestations, is entirely

\footnotetext{
Abbreviations: AGA, anti-gliadin antibodies; BMD, bone mineral density; CD, coeliac disease; DH, dermatitis herpetiformis; EMA, endomysial antibodies; GFD, gluten-free diet; HLA, human leucocyte antigen; tTG, tissue transglutaminase.

*Corresponding author: Professor John H. Cummings, fax + 441382 633952, email j.h.cummings@dundee.ac.uk
} 
Table 1. Presenting features of coeliac disease

\begin{tabular}{l}
\hline Adults: \\
Diarrhoea, altered bowel habit \\
Abdominal pain, dyspepsia, bloating \\
Aphthous ulcers \\
Anaemia (Fe or folate and rarely vitamin $\mathrm{B}_{12}$ ) \\
Weight loss \\
Dermatitis herpetiformis \\
Malabsorption, oedema \\
Osteoporosis, low impact fracture \\
Infants and children: \\
Loss of appetite, failure to thrive, miserable child \\
Malabsorption, diarrhoea, abdominal distension \\
Small stature, muscle wasting \\
Less common symptoms: \\
Tiredness, depression, muscle weakness, amenorrhea, bone \\
pain, infertility \\
No specific symptoms: \\
Seroprevalence studies in health populations \\
Family history \\
Screening in associated conditions (see Table 4) \\
Biopsy during endoscopy for unrelated symptoms
\end{tabular}

treatable by diet. The development in recent years of simple but reliable blood tests to identify CD has led to a great increase in coeliac awareness and understanding of the condition. CD is a subject of substantial research in many countries, and approximately $700-800$ papers on this topic appear annually. The present review will focus on current thinking about $\mathrm{CD}$, particularly from the clinical, nutritional and dietetic perspective. There are a number of recent comprehensive reviews that cover other aspects of the condition (Ciclitira, 2001; Green \& Jabri, 2003; Mowat, 2003; Treem, 2004; Alaedini \& Green, 2005; James, 2005).

\section{Symptoms and clinical manifestations}

Although the diagnosis of CD is reached by many routes, there are some key symptoms or clinical findings that should always raise the possibility of this condition (Table 1). Diarrhoea is the commonest symptom, although its prevalence has diminished in recent years from $73 \%$ of patients to $43 \%$ of patients (Lo et al. 2003), probably because of the increasing numbers diagnosed after screening. Associated with diarrhoea can be abdominal pain, wind and weight loss. Frank steatorrhoea is now rare. In children gastrointestinal symptoms are also a common presenting feature and often go with anorexia and failure to thrive, short stature and, again rarely, the pot-bellied wasted miserable child (Rawashdeh et al. 1996). Other gastrointestinal symptoms include constipation, vomiting, dyspepsia and mouth ulcers. The onset of CD is triggered by weaning in children (Norris et al. 2005), and in adults it can appear to follow a gastrointestinal infection, pregnancy or even surgery. Other features include $\mathrm{Fe}$ or folate deficiency, anaemia, aphthous ulcers or the rash of $\mathrm{DH}$ (Bottaro et al. 1999; Feighery, 1999; Hin et al. 1999; Green et al. 2001; Tursi et al. 2001; Gillett et al. 2003; Lo et al. 2003; Elsurer et al. 2005).
However, increasingly commonly, CD is diagnosed after screening of asymptomatic populations such as blood donors, first-degree relatives, at-risk groups with type 1 diabetes, thyroid disease, osteoporosis or microscopic colitis and incidentally at gut biopsy. In these subclinical or 'silent' versions of CD Fe-deficiency anaemia is a much commoner feature (Bottaro et al. 1999; Hin et al. 1999; Tursi et al. 2001; West et al. 2003a). Once the likelihood of $\mathrm{CD}$ has been raised, patients report minor symptoms that they have had for years such as tiredness, sore mouth, hair loss, abdominal discomfort, wind or abnormal bowel habit, which had previously been taken for granted. Treatment in these cases can often result in marked and unexpected improvements in health.

CD may, therefore, present with almost any symptoms and to any branch of medical practice. The most important step in diagnosis is awareness of its diverse manifestations.

\section{Genetics and pathogenesis}

The pathology of $\mathrm{CD}$ is that of a T-cell-mediated autoimmune disorder, triggered by certain cereal proteins, that affects principally the duodenum and upper jejunum. The normal small bowel mucosa is covered in fine fingerlike projections or villi sitting on top of a thin layer of muscle, the muscularis mucosa, and connective tissue stroma, the lamina propria. The villi are covered in a single layer of epithelial cells that originate in crypts at the base of the villi and play a crucial role in digestion and absorption. Each epithelial cell is covered in microvilli. Villus height:crypt depth is usually $\geq 3: 1$ in healthy adults.

In CD there is complete loss of villi and hypertrophy of the mucosa with infiltration of the lamina propria by inflammatory cells (lymphocytes, plasma cells, eosinophils and mast cells), which results in the so-called flat mucosa characteristic of the condition. A key feature is a migration of lymphocytes to the surface epithelium (intra-epithelial lymphocytes). Intra-epithelial lymphocytes can be found throughout the gut in $\mathrm{CD}$, right down to the rectum, and are the earliest changes to be seen. Varying extents of severity are reported (Marsh, 1992; Whitehead, 1995).

Three factors are essential in relation to the series of events that lead to these pathological changes: genetic susceptibility; the immune system; gluten in the diet. There is a strong genetic component to $\mathrm{CD}$. Concordance is $75-90 \%$ in monozytotic twins and $10-20 \%$ in dizygotic twins. In first-degree relatives the prevalence is $10 \%$ and in second-degree relatives it is $2 \%$. Almost all patients with CD (95\%) carry the human leucocyte antigen (HLA)DRB1*03 (HLA-DQ2 or HLA-DRB*04 DQ8) haplotypes on chromosome 7. Concordance amongst HLA-identical siblings is about 30\% (Auricchio et al. 1999; Greco et al. 2002; Fasano et al. 2003; Maki et al. 2003). Other candidate genes may also be involved (Van Belzen et al. 2003; Diosdado et al. 2004).

Gluten is a water-soluble protein found in wheat. It consists of an alcohol-soluble fraction, gliadin, and an insoluble fraction, glutenin. The gliadin fraction can be further subdivided into $\alpha, \beta, \gamma$ and $\omega$ fractions, all of which 
are toxic in $\mathrm{CD}$, although the $\alpha$ fraction is thought to be the most active. These alcohol-soluble proteins are known as prolamins and are termed gliadin in wheat, hordein in barley, secalin in rye and avenin in oats. A 33-mer peptide, rich in proline and glutamine, has been isolated from gliadin and is thought to contain the toxic sequence (Shan et al. 2002). After digestion of wheat proteins, or barley or rye proteins, by pancreatic enzymes this 33-mer peptide survives, possibly because of the high proline content. It also resists digestion by the brush border and can cross the epithelial cell membrane and pass into the cytosol (Matysiak-Budnik et al. 2003).

This glutamine-rich peptide is then deamidated by transglutaminase enzymes (Skovbjerg et al. 2004). The deamidated epitope cross-links and has a high affinity to the HLA-DQ2 molecule, which is then presented to CD4+ T-cells. These T-cells become activated and secrete inflammatory cytokines etc. (Mowat, 2003), and tissue damage occurs. T-cell lines from patients with $\mathrm{CD}$ also recognise peptide sequences from barley and rye but not oats (Vader et al. 2003). These changes start to occur within 4-6h of exposure to the toxic peptide (Fraser et al. 2003).

\section{Serology and diagnosis}

A number of serological tests have been developed over the years (see Dahele \& Ghosh, 2000), including antireticulin antibodies (now obsolete), anti-gliadin antibodies (AGA; the main serological CD test for many years following its introduction in 1958), endomysial antibodies (EMA; endomysium is a connective tissue protein) and, mostly recently, antibodies to tissue transglutaminase (tTG). Both IgA and IgG AGA antibodies are present in the sera of patients with $\mathrm{CD}$, although they are not specific because gliadin crosses the normal gut mucosa, and approximately $5-10 \%$ of the healthy population will be positive for gliadin antibodies, particularly older individuals. It has been suggested (Dahele \& Ghosh, 2000) that AGA positivity in otherwise healthy individuals may be associated with minor abnormalities on biopsy, but this response may just represent increased sensitivity to other factors such as non-steroidal anti-inflammatory drugs. Both $\mathrm{IgG}$ and IgA AGA are measured, with $\operatorname{IgG}$ showing reasonable sensitivity but poor specificity whilst IgA AGA has better specificity but poor sensitivity (Berger \& Schmidt, 1996; Chartrand et al. 1997; Dahele \& Ghosh, 2000).

EMA were first described in CD about 20 years ago (Chorzelski et al. 1984) and rapidly replaced AGA as the serological test of choice because of their high specificity, which approaches $100 \%$. Initially, however, the test was not popular because it required monkey oesophageal tissue as substrate. Since 1994, however, human umbilical cord has been used as substrate and has proved to be even more sensitive and specific than using monkey oesophagus. EMA are not found in healthy individuals, unlike AGA, although false positives have been reported in children with associated gastrointestinal problems. False negatives do occur, especially in children, and where the mucosal lesion is less severe (Kumar et al. 1989; Lerner et al. 1994;
Valdimarsson et al. 1996). Dieterich et al. (1997) have identified tTG as the auto-antigen with which EMA reacts. The subsequent development of an accurate and inexpensive ELISA for tTG, together with its high sensitivity and specificity, has led to a move towards using tTG as the serological test of choice for the diagnosis of CD (Bazzigaluppi et al. 1999; Biagi et al. 1999; Gillett \& Freeman, 2000a; Fabiani et al. 2004; Reif \& Lerner, 2004; PG Hill, JM Forsyth, D Semeraro and GKT Holmes, unpublished results).

Low levels of tTg antibody can occur in biopsy-proven CD. However, low or negative antibody tests in suspected CD should always raise the possibility of selective $\operatorname{IgA}$ deficiency, which is found in $2-3 \%$ of individuals with $\mathrm{CD}$, and which affects not only $\mathrm{tTg} \operatorname{IgA}$ antibodies but also EMA and AGA IgA antibodies. In these circumstances it is recommended that IgA levels are measured and then EMA or tTG IgG antibodies are used to screen for CD (Cataldo et al. 2000; Korponay-Szabo et al. 2003; Lenhardt et al. 2004). Hill et al. (2004) have suggested that if tTG antibodies are low $(<2.9$ units $/ \mathrm{ml})$ EMA (IgA) should be measured, and if EMA is positive a biopsy should be done; if EMA is negative $\operatorname{IgA}$ should be measured. Screening serology may still be negative in the presence of $\mathrm{CD}$ and normal IgA levels (Dickey et al. 2000a; Rostami et al. 2000; Sanders et al. 2005). This outcome poses a real diagnostic problem. Where clinical suspicion of $\mathrm{CD}$ is high, especially in the presence of risk factors such as family history or type 1 diabetes, then biopsy is necessary and remains the ultimate diagnostic test.

Serum tTG IgA antibodies, or other antibody levels, may also be low because the patient is on a gluten-free diet (GFD). Both tTG and EMA decline in the months following instigation of GFD; by 6 months they will be low and by 12 months they will be negative (Dickey et al. 2000b; Tursi et al. 2003; F Moor, JM Forsyth, PG Hill and GKT Holmes, unpublished results). In some patients antibody levels decline within 4 weeks of starting a GFD, so it is important that patients do not start a GFD until the diagnosis of CD has been established beyond doubt (Midhagen et al. 2004). It is not known how long it takes for antibody positivity to develop after the introduction of gluten in CD. If an adult patient has already changed diet it is recommended that they need to have $\leq 10 \mathrm{~g}$ gluten (four slices of bread daily) for 6 weeks before blood testing or gut biopsy (Wahab et al. 2001). In the case of children gluten is given either as a fixed daily amount of $5 \mathrm{~g}$ or as a free intake of gluten-containing products. For children who may already be on a GFD it may be preferable to use a gluten powder rather than introducing normal gluten-containing foods at this stage.

The usual sequence of events in the diagnosis of CD is, therefore, as follows: clinical suspicion based on symptoms, signs, associated disease or screening in asymptomatic individuals $\rightarrow$ positive serology $\rightarrow$ intestinal biopsy $\rightarrow$ response to GFD. Whilst biopsy is currently regarded as the gold standard for diagnosis, the characteristic 'flat' mucosa of CD is not always seen and various grades of severity are described (Marsh, 1992). Other conditions, such as tropical sprue, protein-energy malnutrition or cow's milk allergy in children, can produce 
Table 2. Studies published since 1997 that have used either antibodies to tissue transglutaminase (tTG) or endomysial antibodies (EMA) to determine the prevalence of coeliac disease

\begin{tabular}{|c|c|c|c|c|c|c|}
\hline Reference & Country & Population & $n$ & Test & Biopsy positive & Rate \\
\hline Maki et al. (2003) & Finland & $\begin{array}{l}\text { Schoolchildren 7-16 } \\
\text { years }\end{array}$ & 3654 & EMA, tTG & $\begin{array}{l}\text { Twenty-seven } \\
\text { of thirty-six }\end{array}$ & $1: 99$ \\
\hline Tatar et al. (2004) & Turkey & Blood donors & 2000 & tTG & Seven of twelve & $1.3 \%$ \\
\hline Not et al. (1998) & USA & Blood donors & 2000 & AGA, EMA & - & $1: 250$ \\
\hline West et al. (2003b) & UK & $\begin{array}{l}\text { Health study, subjects } \\
\quad 45-76 \text { years }\end{array}$ & 7550 & EMA & - & $1 \cdot 2 \%$ \\
\hline Hovell et al. (2001) & Australia & Health study & 3011 & EMA & Yes & $1: 251$ \\
\hline Castano et al. (2003) & Italy & Children $1.5-2.5$ years & 613 & tTG & Yes & $1: 118$ \\
\hline Fasano et al. (2003) & USA & Adults & 4126 & AGA, EMA, tTG & Yes & $1: 133$ \\
\hline Bingley et al. (2004) & UK & Children 7.5 years & 5470 & tTG & Not done & $1 \cdot 0 \%$ \\
\hline Corazza et al. (1997) & Italy & Adults $20-87$ years & 2237 & EMA & Yes & $0.18 \%$ \\
\hline $\begin{array}{l}\text { Lohi et al.* } \\
\text { (unpublished results) }\end{array}$ & Finland & Stored sera & 7217 & EMA, tTG & - & $1: 93$ \\
\hline $\begin{array}{l}\text { Mustalahti et al. } \dagger \\
\quad \text { (unpublished results) }\end{array}$ & Finland & Adults $>30$ years & 6403 & tTG & $64 \%$ & $1: 49$ \\
\hline \multirow[t]{6}{*}{ Jarry (2003) } & Northern Ireland & Adults $32-64$ years & 4656 & tTG & $27 \%$ & $1: 63$ \\
\hline & & Children $12-15$ years & 1975 & tTG & - & $1: 100$ \\
\hline & Italy & Adults and children & 4814 & tTG & - & $1: 71$ \\
\hline & & Children $11-14$ years & 2612 & tTG & - & $1: 80$ \\
\hline & Germany & Adults $25-74$ years & 4633 & tTG & $63 \%$ & $1 \cdot 74$ \\
\hline & & Adults $25-74$ years & 4173 & tTG & - & $1: 232$ \\
\hline Schweizer et al. (2004) & The Netherlands & Adults & 1440 & Not given & - & $0.35 \%$ \\
\hline Lagerqvist et al. (2001) & Sweden & Adults $25-74$ years & 1850 & EMA, tTG & Yes & $1: 168$ \\
\hline Csizmadia et al. (1999) & The Netherlands & Children & 6127 & EMA & Yes & $1: 198$ \\
\hline Pratesi et al. (2003) & Brazil & Adults and children & 4405 & EMA & Yes & $0.34 \%$ \\
\hline Gandolfi et al. (2000) & Brazil & Blood donors & 2045 & EMA & Yes & $1: 681$ \\
\hline Gomez et al. (2001) & Argentina & Adults & 2000 & EMA & Yes & $1: 167$ \\
\hline Kolho et al. (1998) & Finland & Adults & 1070 & EMA & Yes & $1: 130$ \\
\hline Johnston et al. (1997) & Northern Ireland & Adults & 1823 & EMA, AGA & Some & $1: 122$ \\
\hline
\end{tabular}

AGA, anti-gliadin antibodies.

*S Lohi, K Mustalahti, K Laurila, O Lohi, H Rissanen, A Reunanen and M Maki.

†K Mustalahti, A Reunanen, M Heuer, M-H Metzger, E Fabiani, C Catassi, L Murray, S McMillan, M Caradonna, E Bravi and M Maki.

a similar picture. In practice, a combination of positive serology and a biopsy in keeping with $\mathrm{CD}$ are usually required to put the diagnosis beyond doubt and, thus, justify a lifelong change in diet (Abdulkarim \& Murray, 2003). The European Society for Paediatric Gastroenterology, Hepatology and Nutrition (Walker-Smith, 1990) has published revised criteria for the diagnosis of $\mathrm{CD}$, with one biopsy replacing the three originally recommended. The North American Society for Paediatric Gastroenterology, Hepatology and Nutrition (Hill et al. 2005) has developed a clinical practice guideline for the diagnosis and treatment of $\mathrm{CD}$ in children, and recommends that testing of asymptomatic children who belong to at-risk groups begins at 3 years of age, provided that they have been on an adequate gluten-containing diet for at least 1 year before testing. For adults guidelines have been laid out by the British Society of Gastroenterology (2002).

\section{Prevalence}

The prevalence of $\mathrm{CD}$ is only now emerging, $>50$ years after the original intestinal biopsies were done. The development of sensitive and specific serology for CD has opened up new horizons in case finding and diagnosis. Table 2 lists the results of twenty studies published since 1997 that have used either tTG or EMA to determine the prevalence of $\mathrm{CD}$. Overall, these studies involved the screening of 87904 individuals and the prevalence in these individuals is $1: 103$, or effectively $1 \%$, which makes CD one of the most prevalent inherited disorders. A recent systematic review of CD prevalence, focusing on the USA and Europe, also reports a value of $1 \%$, with a statistical range of probability of $0 \cdot 5-1 \cdot 26 \%(1: 200-1: 70$; Dube et al. 2005).

In terms of the reliability of these data, it is almost certain that they are still an underestimate, because in many studies existing CD cases are not included, very young children have been tested when they may not yet have developed antibodies (Norris et al. 2005) and diagnostic criteria may be too rigid. However, not all the prevalence data in Table 2 include both serology and biopsy, which are still both needed for a diagnosis. Furthermore, whilst biopsy remains the gold standard test, its interpretation is by no means black and white. Tiny pieces of tissue are obtained at endoscopy, approximately 2-3 mg, and sampling errors can occur. Moreover, as Marsh (1992) has clearly shown, there are extents of gut damage and early changes such as the presence of a 
few intra-epithelial lymphocytes that are not necessarily considered diagnostic.

There may also be true regional differences in prevalence. Data in Table 2 give a prevalence of 1:94 $(1.07 \%)$ for European countries, $1: 157(0.64 \%)$ for the USA, but for the three reports from South America, the rate is $1: 281(0 \cdot 36 \%)$. However, whilst the European data may be quite robust, the numbers are too small as yet for North and South America to allow discussion of regional variations. More data are needed, especially for the subcontinents of China and India. Nevertheless, the strong genetic background of $\mathrm{CD}$ and dietary patterns mean regional variations are likely.

\section{Pregnancy and breast-feeding}

Untreated, or undiagnosed, CD is associated with a number of unfavourable fertility and pregnancy outcomes (Norgard et al. 1999; Martinelli et al. 2000; Kotze, 2004; Ciacci et al. 2005). About half the women affected show delayed menarche, reduced fertility and an increase in spontaneous abortion rate. In a UK general-practice-based study (Tata et al. 2005) it has been found that crude fertility rates are similar for women with or without CD but age-specific rates are lower for younger patients with $\mathrm{CD}$. For example, fertility rate ratios for women with $\mathrm{CD}$ : women without $\mathrm{CD}$ are $0.40(95 \% \mathrm{CI} 0 \cdot 16,0 \cdot 99)$ for age $15-19 \cdot 9$ years and $0.84(95 \%$ CI $0.61,1 \cdot 16)$ for age $20-24.9$ years, whilst in older age-groups fertility rates are greater, 1.39 (95\% CI $1.06,1.83$ ) for age 35-39.9 years, indicating that women with CD probably have their babies at a later age, which is consistent with the socio-economic profile of women with $\mathrm{CD}$. The relative risk for miscarriage is $\leq 8.9$ (Ciacci et al. 1996) and intrauterine growth retardation occurs, with average birth weights that are $\leq 800 \mathrm{~g}$ lower (Martinelli et al. 2000; Ciacci et al. 2005). Of the couples who are infertile $3 \%$ have $\mathrm{CD}$, and in couples with otherwise unexplained infertility the rate is $8 \%$. Male fertility may be affected (Meloni et al. 1999). Adherence to a GFD, however, reduces these risks to the same as that in the rest of the population (Ciacci et al. 1996; Norgard et al. 1999; Martinelli et al. 2000), but may not affect fertility rates (Tata et al. 2005). Moreover, the risks to baby and mother may be less in those individuals who have only minor symptoms of CD and are diagnosed by screening blood test, although the risk of anaemia and spontaneous abortion remains (Greco et al. 2004).

The advice on nutrition (Department of Health, 1996) and alcohol intake (Department of Health, 1995; Royal College of Obstetricians and Gynaecologists, 1999) given to women with $\mathrm{CD}$ who become pregnant whilst adhering to a GFD should be similar to the general dietary guidance given during pregnancy, including preconceptual supplementary folic acid $(400 \mu \mathrm{g} / \mathrm{d})$, which should be continued throughout the first trimester of pregnancy (Department of Health, 2000). There are no specific recommendations on $\mathrm{Ca}$ intake during pregnancy, but the advice should be tailored to the individual. Supplementation needs to be considered on an individual basis, with particular reference to $\mathrm{Fe}, \mathrm{Ca}$, folic acid and vitamin $\mathrm{B}_{12}$ status.
Once the baby is born the question arises as to when to introduce gluten-containing foods. The UK Department of Health (1994) and Food Standards Agency (2002), the World Health Organization (Kramer \& Kakuma, 2002) and the American Academy of Pediatrics (Hill et al. 2005) recommend breast milk alone for the first 6 months and no wheat-based foods. In Sweden Ivarsson et al. (2000, 2002) have studied a large group (627) of subjects with CD and controls (1254) and have related $C D$ to infant feeding patterns. They suggest that the risk of $\mathrm{CD}$ is reduced (OR $0.59(95 \%$ CI $0.42,0.83))$ if breast-feeding is continued when gluten-containing foods are introduced, and they recommend that these foods are introduced gradually. In Sweden gluten-free foods are allowed at between 4 and 6 months (van Odijk et al. 2004), although half the mothers delay introducing them until 6 months. In the UK the British Dietetic Association's Paediatric Group Position Statement on Breastfeeding on to Solid Foods (British Dietetic Association, 2005) states that 4 months or 17 weeks should be regarded as the earliest age at which solids should be introduced and that gluten-containing foods should not be introduced until after 6 months.

In a prospective study of 1560 children in the USA at increased risk of CD (having either HLA-DR3 or DR4 alleles) exposure to wheat, barley or rye in the first 3 months of life has been shown to increase the risk of CD fivefold compared with those who are not exposed until 4-6 months (Norris et al. 2005). Interestingly, in this study, in which children had tTG antibody levels measured regularly from age 9 months, the mean age at which the first positive test was recorded was found to be 4.7 (SD $1.5)$ years. Studies in other countries, although perhaps not as comprehensive, have not found a relationship between the timing of the introduction of gluten-containing foods and risk of CD (Cataldo et al. 1995; Ascher et al. 1997; Peters et al. 2001). However, Peters et al. (2001) have shown a substantial lowering of risk for developing CD in children breast-fed for $>2$ months as compared with those breast-fed for $<2$ months, including partial breast-feeding. Introduction of wheat before 6 months is more likely to lead to failure to thrive, whilst breast-fed children who develop CD are often diagnosed late and have milder and more atypical symptoms (D'Amico et al. 2003).

This area is a very important for further prospective studies. If the risk of $\mathrm{CD}$ can be reduced by continuous breast-feeding and avoidance of gluten, then prevention of $\mathrm{CD}$ becomes possible and a lot of questions about its cause are raised. Meanwhile, gluten should not be introduced before 6 months and any weaning foods before this time should be gluten-free. This advice is particularly important for families in which there is a history of CD. Breast milk is protective and can delay the onset of symptoms in predisposed infants.

\section{Risk of malignancy}

There is undoubtedly an increased risk of malignancy in $\mathrm{CD}$, but this risk is probably confined to two quite rare types of cancer (Table 3) and diminishes with time from diagnosis and with good dietary compliance. Almost as 
Table 3. Risk of cancer in coeliac disease

\begin{tabular}{ll}
\hline Increased & Decreased \\
\hline Definite & Breast \\
Non-Hodgkins lymphoma & \\
Small bowel adenocarcinoma & Lung \\
Possible & \\
Oesophagus & \\
Melanoma & \\
Large bowel & \\
Liver & \\
Oropharyngeal & \\
Pancreas & \\
No change & \\
Stomach & \\
Prostate & \\
Ovary & \\
Brain & \\
\hline
\end{tabular}

soon as CD had been defined and small bowel biopsy became popular, there was shown to be an increased risk of lymphoma of the small bowel (Gough et al. 1962). Reports then followed on increased risk of gastrointestinal malignancy such as orophoryngeal and oesophageal cancer (Holmes et al. 1989; Logan et al. 1989) and, more recently, other cancer risks have been identified in some but not all studies, e.g. melanoma, liver and pancreatic cancer (Askling et al. 2002; Green et al. 2003). Risk of adenocarcinoma of the small bowel has been found to be consistently increased (Askling et al. 2002; Howdle et al. 2003; Peters et al. 2003; Rampertab et al. 2003).

The principal cancer that is increased in $\mathrm{CD}$ is lymphoma, of which non-Hodgkins lymphoma is the principal type. Both B- and T-cell non-Hodgkins lymphomas occur, with the T-cell type probably being the more common (Catassi et al. 2002; Green et al. 2003; Smedby et al. 2005), depending on the population being studied. However, it should be remembered that whilst the risk of non-Hodgkins lymphoma may be increased by between 3 -fold and 9-fold, the overall risk to the population is $<1 \%$ and so this type of cancer remains uncommon even in CD. Similarly, adenocarcinoma of the small bowel, although ten to thirty-four times more common in $\mathrm{CD}$ (Askling et al. 2002; Peters et al. 2003; Green et al. 2003), nevertheless remains a very rare tumour.

On a more positive note, the risk of some of the very common cancers appears to be reduced in $\mathrm{CD}$, particularly breast cancer, for which the risk is reduced to about onethird (Askling et al. 2002; Card et al. 2004; West et al. $2004 b$ ), and lung cancer, which is reduced in some studies (West et al. 2004b). However, the Nottingham group, who have reported observations in this area of $\mathrm{CD}$ and malignancy since 1989 , have noted that fewer patients with CD are smokers (Austin et al. 2002). The mechanism that leads to these reduced risks needs further research.

Equally encouraging is the observation that risk of malignancy, except possibly non-Hodgkins lymphoma, diminishes with time after diagnosis of $\mathrm{CD}$ and by 15 years the overall risks are no different from those for the general population (Askling et al. 2002; West et al. 2004b). $\mathrm{CD}$ diagnosed in childhood carries no additional risk of
Table 4. Conditions more common in coeliac disease

Diabetes (type 1)

Thyroid disorders (autoimmune or Graves)

Sjogren's syndrome

Adrenocortical failure (Addisons)

Liver disease (raised transaminases and primary biliary cirrhosis)

IgA deficiency

Lymphocytic or microscopic colitis

Down's syndrome

Unusual neurological disorders

Dental enamel defects

Turner syndrome

malignancy. Most importantly, the risk diminishes only in those compliant with a GFD (Holmes et al. 1989; Logan et al. 1989; Corrao et al. 2001), although Ciacci et al. (2005) have reported that diagnosis in childhood and gluten withdrawal is protective even if individuals subsequently become re-exposed to gluten.

Cancer risks are probably not increased in DH (Askling et al. 2002) unless patients fail to adhere to a GFD, in which case the risk of lymphoma is increased (Hervonen et al. 2005).

Overall, there is clearly increased risk for two types of cancer, lymphoma and adenocarcinoma of the small bowel. However, the risk of breast cancer is reduced and possibly also the risk of lung cancer. Moreover, the risk appears to diminish following diagnosis and is the same as that for the general population after 15 years on a GFD. CD diagnosed in childhood carries no extra risk of malignancy, neither does DH. However, the fundamental precondition is that a strict GFD is followed.

\section{Associated conditions}

A number of diseases seem to occur more commonly in CD (Collin et al. 1994; Feighery, 1999; Table 4). Of these conditions, type 1 diabetes is probably the most important, occurring in about $5 \%$ of patients with $\mathrm{CD}$, and when patients with type 1 diabetes are screened for CD 6-10\% are antibody and/or biopsy positive (Gillett et al. 2001; Hansen et al. 2001; Not et al. 2001; Valerio et al. 2002; Arato et al. 2003; Ashabani et al. 2003). Moreover, the siblings of children with diabetes, who do not have diabetes themselves, show an increased frequency of $C D$ of 1.9-3.8\% (Not et al. 2001; Sumnik et al. 2005) and the risk of type 1 diabetes is also increased in individuals with DH $(2.3 \%)$ and their relatives (3\%; Hervonen et al. 2004). A common genetic predisposition has been suggested, with HLA-DQB $1 * 02$ or $* 0302$ present in all patients with both conditions (Martin-Villa et al. 2001; Saukkonen et al. 2001). Patients with diabetes who have CD show signs of poor nutrition (Hansen et al. 2001) and improve with a GFD, with which they show good compliance (Not et al. 2001; Saadah et al. 2004). Thus, screening of all patients with type 1 diabetes and probably their first-degree relatives is desirable.

Approximately $5 \%$ of the patients with $\mathrm{CD}$ have thyroid disorders (either autoimmune (Hashimoto's) or Graves 
disease), about twice the prevalence in the general population (Collin et al. 1994; Ciacci et al. 2005). Again, it is worth screening patients with these disorders for $C D$, because the prevalence of $\mathrm{CD}$ in Graves disease is about 4.5\% (Ch'ng et al. 2005) and patients with Hashimoto's disease who are sero negative for CD show increases in the number of $\gamma \delta$ T-cell receptors bearing I-E lymphocytes and increases in mucosal T-cell activation (Valentino et al. 2002), which could be construed as early or subclinical CD.

Other autoimmune disorders seen in CD include Sjogren's syndrome (a chronic inflammatory disorder of probable autoimmune nature characterised by infiltration of the exocrine glands, particularly the salivary and lacrimal (tear) glands, by lymphocytes and plasma cells), about 3\% of patients with CD (Collin et al. 1994), and when patients with Sjogren's syndrome are screened for CD $4.5 \%$ are biopsy positive for CD (Szodoray et al. 2004). In patients with adrenocortical failure, of whom 7-12\% are reported to have CD (O'Leary et al. 2002; Myhre et al. 2003), screening for CD again seems worthwhile.

Untreated $\mathrm{CD}$ is frequently associated with silent liver disease, i.e. elevated levels of transaminases. A recent systematic review of this condition by Duggan \& Duggan (2005) has identified six studies that include liver biochemistry, indicating that $42 \%$ of the patients newlydiagnosed with $\mathrm{CD}$ have raised transaminases. Treatment with a GFD leads to the majority of biochemical and early histological abnormalities reverting to normal. Conversely, $3-4 \%$ of the patients with non-alcoholic steatohepatitis have biopsy-positive CD (Bardella et al. 2004). In 10\% of Italian patients with biliary cirrhosis there is an increased risk of CD (Floreani et al. 2002), but no risk of CD is apparent in Poles (Habior et al. 2003). Cholestatic liver disease has also been reported (Lawson et al. 2005).

Finally, there are a number of other associated disorders such as Down's syndrome (Morris et al. 2000; Goldacre et al. 2004), unusual neurological conditions (Feighery, 1999), lymphocytic and microscopic colitis (Gillett \& Freeman, 2000b; Olesen et al. 2004), dental enamel defects (Ciacci et al. 2005), depression (Addolorato et al. 2001; Ciacci et al. 2005) and Turner syndrome (a rare chromosomal disorder (usually XX) of females characterised by short stature and lack of sexual development at puberty; Gillett et al. 2000).

There is no rational explanation for this disparate collection of disorders, but it is clearly worth screening patients with type 1 diabetes, thyroid disease, adrenocortical failure, Sjogren's syndrome, unexplained raised levels of liver transaminases and microscopic colitis for CD.

\section{Bones}

One of the earliest observations, in the 1930s, in patients with CD presenting with classic malabsorptive symptoms was the association with bone disease, particularly osteomalacia (Bennet et al. 1932). What was not apparent at the time was the higher prevalence of less-severe bone disease in $\mathrm{CD}$, which has only become apparent with the advent of dual-energy X-ray absorptiometry in the late 1980s
(Caraceni et al. 1988). Since then, there have been a number of reports showing clear evidence of reduced bone mineral density (BMD), osteopenia or osteoporosis in $20-50 \%$ of the patients newly diagnosed with CD (Butcher et al. 1992; Corazza et al. 1995, 1996; McFarlane et al. 1995; Kemppainen et al. 1999a; Cellier et al. 2000; Meyer et al. 2001). 'Thin' bones are, therefore, the commonest complication of CD.

The cause of this disorder is likely to be chronic malabsorption of $\mathrm{Ca}$, leading to secondary hyperparathyroidism and increased bone turnover. Contributing factors may be reduced physical activity, low $\mathrm{Ca}$ intakes and low BMI. Increases in markers of bone turnover, formation and resorption, such as bone-specific alkaline phosphatase, urinary hydroxyproline, serum osteocalcin and procollagen I carboxyterminal propeptide, are seen in untreated CD (Corazza et al. 1995; Sategna-Guidetti et al. 2000), along with increased levels of intact serum parathyroid hormone and serum 1,25-dihydroxycholecalciferol. Similar changes in bone are also seen in Crohn's disease, but what is surprising about the finding in $\mathrm{CD}$ is the occurrence of osteopenia or osteoporosis even in patients with very minor presenting symptoms.

The consequences of these bone changes are probably an increase in aches and pains but possibly not much risk of fracture. Increased fracture is reported in a number of big studies of CD, but the risk is small. In 4732 patients with $\mathrm{CD}$ in the UK the hazard ratio for hip fracture was found to be $1.90(95 \%$ CI $1.20,3.02)$, and for fracture of the ulna or radius 1.77 (95\% CI 1.35, 2.34; West et al. 2003a). Higher risks have been reported (Vazquez et al. 2000), which interestingly may relate to the severity of presenting symptoms. Moreno et al. (2004), in 148 patients newlydiagnosed with $\mathrm{CD}$, have shown that in the patients who presented with chronic diarrhoea, overt malabsorption, weight loss and malnutrition the fracture risk in the peripheral skeleton is increased compared with age- and gender-matched controls (odds ratio $5 \cdot 2$ (95\% CI $2 \cdot 8$, $9 \cdot 8)$ ), while in those patients who presented subclinically with anaemia or osteopenia or just on screening the fracture risk is not increased compare with the controls (odds ratio $1.7(95 \%$ CI $0.7,4.4)$ ). In some studies no increase in fracture risk has been observed (Vestergaard \& Mosekilde, 2002; Thomason et al. 2003), probably because large numbers of patients need to be studied to detect small changes in risk.

BMD does improve with a GFD but may not return to that seen in a matched population (Corazza et al. 1995; McFarlane et al. 1995; Sategna-Guidetti et al. 2000; Pazianas et al. 2005). A study that followed patients with CD on a GFD for 5 years (Kemppainen et al. 1999b) has shown that BMD is increased by $2 \%$ in the lumbar spine, $1 \%$ at the femoral neck and $6 \%$ at the femoral trochanter, with most of this increase occurring in the first year of treatment. Any halt to the progressive decline in BMD seen in older women particularly is important. Patients who start off with secondary hyperparathyroidism seem to do less well after 3 years on a GFD (Valdimarsson et al. 2000).

Management of low BMD and CD, apart from a GFD, should follow conventional lines, including increasing 
Table 5. Nutritional indices in subjects with coeliac disease

\begin{tabular}{l} 
At presentation: \\
Reduced $\mathrm{BMI}$ \\
Low serum $\mathrm{Ca}$ \\
Reduced $\mathrm{Hb}$ \\
Reduced serum or erythrocyte ferritin \\
Reduced serum albumin \\
Low plasma cholesterol \\
Low serum folic acid \\
Raised plasma homocysteine \\
Long-term problems: \\
Ca and bones \\
Folate \\
Fe \\
\hline
\end{tabular}

exercise, stopping smoking, avoiding alcohol excess and ensuring an adequate $\mathrm{Ca}$ intake of $\geq 1.5 \mathrm{~g} / \mathrm{d}$ in adults (the recommended $\mathrm{Ca}$ intake for adults with $\mathrm{CD}$ is $1.5 \mathrm{~g} / \mathrm{d}$; Scott et al. 2000) using supplements if necessary. Dairy products such as milk, cheese and yoghurt should be incorporated to provide prime sources of $\mathrm{Ca}$ (Scott et al. 2000). Hormone-replacement therapy is useful in postmenopausal women, and in persistent osteopenia biophosphonates are of proven benefit (Scott et al. 2000). Reduced BMD is also seen in DH, although to a lesser extent than in CD, except where BMI is $<20 \mathrm{~kg} / \mathrm{m}^{2}$ (Di Stefano et al. 1999).

\section{Potential nutritional problems}

At presentation, or on diagnosis, subjects with $\mathrm{CD}$ show clear differences in nutritional status from non-CD controls (Kemppainen et al. 1998; Sategna-Guidetti et al. 2000; Tursi et al. 2001; Gillett et al. 2003; Ciacci et al. 2005; W Dickey, M Ward, M Traynor, C Hackett, G Horigan, S Patton, M O'Kane and H McNulty, unpublished results). Table 5 lists the most consistently found differences, which include body weight (BMI reported in the range 18-20 kg/ $\left.\mathrm{m}^{2}\right)$, lower $\mathrm{Hb}(1.2 \mathrm{~g} / \mathrm{l}$ compared with $1.3 \mathrm{~g} / \mathrm{l}$ in controls) and low ferritin and $\mathrm{Fe}$, albumin, $\mathrm{Ca}$, cholesterol and folate, associated with raised plasma homocysteine. These differences do not qualify as deficiencies and not all newly-diagnosed patients with CD show them. Nevertheless, they improve with a GFD (Sategna-Guidetti et al. 2000) and are less marked in partly-treated patients (Ciacci et al. 2005). They are consistent with generalised malabsorption associated with a defect in transport in the duodenum and jejunum. Occasional reports of vitamin $\mathrm{B}_{12}$ deficiency (see Kemppainen et al. 1998) are less easy to understand.

Surprisingly, there are very few papers on any long-term problems associated with nutrition in $\mathrm{CD}$, apart from the well-recognised complication of osteoporosis to which a number of factors may contribute (see earlier discussion, p. 440). At presentation patients with $C D$ have a lower BMI than matched controls, which seems to continue in the long term. At three-yearly follow-up a group of seventy-one adult patients with CD seen in an Italian clinic, who were on a strict GFD and asymptomatic,

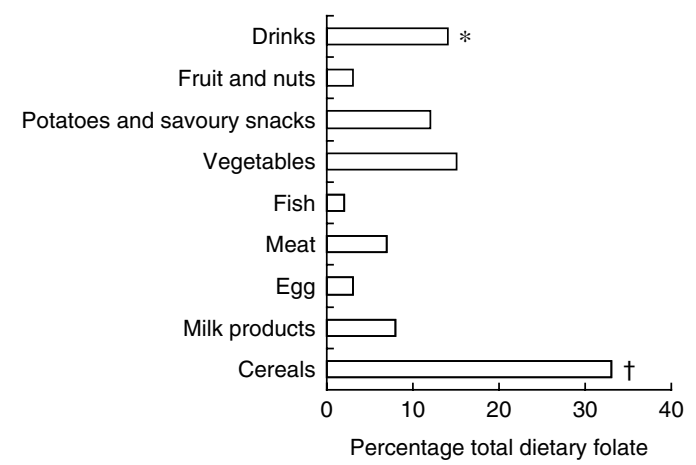

Fig. 1. Sources of dietary folate. ${ }^{*}$ Beer $8 \%$. † Breakfast cereals 15\%. (From Henderson et al. 2003.)

underwent nutritional and dietary assessment (Bardella et al. 2000). BMI $\left(\mathrm{kg} / \mathrm{m}^{2}\right)$ was found to be significantly lower than in a control population in both men (21.9 (SD 2.9) for men with CD v. 23.5 (SD 2.9) for the controls; $P>0.05$ ) and women (20.9 (SD 2.7) for women with CD v. 22.4 (SD 4.3) for controls; $P<0.03$ ), and energy intakes were found to be lower by $1000-1500 \mathrm{~kJ}$. Body fat and lean body mass were also found to be lower in patients with $\mathrm{CD}$.

However, most patients with $\mathrm{CD}$ seem to put on weight after starting a GFD (Hallert et al. 2002), and the reported lower BMI may be related to the fact that patients with $\mathrm{CD}$ are more health-conscious than the increasinglyobese general population rather than to a GFD leading to inadequate energy intake (GG Robins, S Hamlin and PD Howdle, unpublished results).

More importantly, however, there may be long-term problems with folate status. In a study of thirty adults with $\mathrm{CD}$ in biopsy-proven remission for 8-12 years on a GFD (Hallert et al. 2002) low plasma folate levels were found in $20 \%$ of the subjects and low pyridoxal $5^{\prime}$-phosphate levels in $37 \%$ of the subjects. Mean daily folate intake was also significantly lower for patients with CD $(184 \mu \mathrm{g} / \mathrm{d})$ than for the controls $(206 \mu \mathrm{g} / \mathrm{d} ; P<0 \cdot 05)$. Plasma homocysteine concentrations were found to be significantly higher for male patients with $\mathrm{CD}(13.6 \mu \mathrm{mol} / \mathrm{l})$ than for controls $(11.2 \mu \mathrm{mol} / 1 ; \quad P<0.05)$ and were also higher, but not significantly, in female patients with CD.

Clearly, more studies that look at vitamin and mineral status in $\mathrm{CD}$ in the long term are needed; with raised plasma homocysteine now linked to increased risk of CVD (Kerins et al. 2001) and low folate intakes linked to colo-rectal cancer (Mason, 2002) these findings could be important. They are also relevant because $33 \%$ of the dietary folate comes from cereals and a further $8 \%$ from beer, both restricted food groups for individuals with CD (Fig. 1).

The importance of chronic problems with nutrition is unclear, apart from those related to bone disease. However, a disturbing preliminary report from Finland (Verkasalo et al. 2003) has indicated that twenty-one of 2427 Finnish adults attending a cardiovascular risk clinic were found to be antibody positive for tTg and EMA, but were not known to have CD. Fewer of the antibody-positive group had a university degree $(5 \cdot 3 \%$ for those who were antibody 
positive $v .15 .6 \%$ for the rest) or were in 'executive or expert positions in (their) working life' (28\% for those who were antibody positive $v .45 \%$ for the controls). The authors have suggested that subjects with 'silent' CD might have concentration difficulties at school. A study of adolescents with newly-diagnosed CD (Pynnonen et al. 2005) has shown that pre-GFD those subjects with depression had lower blood tryptophan:competing amino acid values and free tryptophan concentrations compared with those subjects without depression. The improvements in serum competing amino acid levels and in behaviour after 3 months on a GFD give support to previous findings in patients with CD that they show symptoms of depression and disruptive behaviour, in theory related to serotonergic dysfunction, in general preceding diagnosis and treatment with the GFD (Pynnonen et al. 2004). Furthermore, these improvements suggest that serotonergic dysfunction related to impaired availability of tryptophan may play a role in vulnerability to depressive or behavioural problems in untreated CD.

On a more positive note, death from CVD is thought to be reduced in CD (Whorwell et al. 2004) and risk factors for CVD are reduced in undiagnosed (sero-positive) subjects compared with controls chosen from the General Practice research database, which is a longitudinal primarycare database for more than eight million registered individuals (West et al. 2003b). These factors include lower blood cholesterol, lower LDL-cholesterol, lower BMI, lower blood pressure and fewer smokers. In established CD rates of myocardial infarction and stroke do not seem to be markedly different (West et al. 2004a); nevertheless, blood pressure is lower, as is blood cholesterol.

\section{Dietary management}

Treatment for $\mathrm{CD}$ requires elimination of the gluten found in wheat, barley and rye from the diet (Anderson et al. 2000). Studies in recent years indicate that avenins from oats are not toxic for patients with CD, either for adults (Janatuinen et al. 2002) or children (Hogberg et al. 2004), but recommendations on the inclusion of oats in the GFD vary in practice. One major issue in relation to the safety of oat products is contamination with gluten-containing cereals (Thompson, 2005). In addition, some patients with $\mathrm{CD}$ are sensitive to uncontaminated oats, so individual advice on suitability and safe amounts needs to be based on monitoring and review of progress (Lundin et al. 2003). The GFD can be restrictive in terms of elimination of staple foods such as bread, pasta and breakfast cereals, and replacement with gluten-free alternatives. There is limited information available about the composition of specialist gluten-free products. However, there is evidence from the USA that they may be lower in fibre, Fe, folate, thiamin, riboflavin and niacin (Thompson, 1999, 2000, 2005). Management of a GFD is based on using gluten-free cereals such as rice, millet (Panicum milaiceum), maize and buckwheat (Fagopyrum esculentum Moench.) and also including a variety of other grains, seeds and starchy sources, including amaranth (Amaranthus caudatus L.), teff (Eragrostis tef), quinoa (Chenopodium quinoa Willd.),
Table 6. Checklist of gluten-free foods

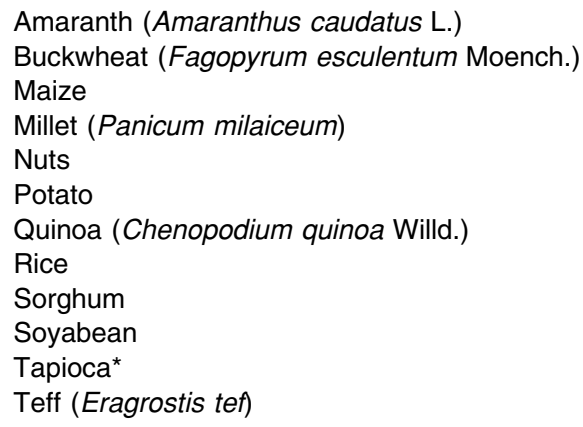

*Starch derived from the cassava (Manihot esculenta) root.

soyabean, potato and plantains (Musa paradisiaca L.; Table 6).

\section{Dietary compliance}

Dietary compliance is key in the successful treatment of CD (Case, 2005). There is evidence to suggest that adherence to the GFD of patients diagnosed with CD depends on the severity of symptoms; the more symptomatic the patient the greater the adherence to the GFD (Westman et al. 1999). Numerous studies indicate that adult dietary compliance tends to be varied (17-45\%; Kluge et al. 1982; Mayer et al. 1991; Bardella et al. 1994; Vahedi et al. 2003). There is an indication that dietary compliance is better when the $\mathrm{CD}$ is diagnosed in early childhood (Fabiani et al. 2000; Hogberg et al. 2004).

Dietary compliance can be assessed by diet history or measurement of serum antibodies (Burgin-Wolff et al. 2002, Ciacci et al. 2002). Non-compliance may occur for a number of different reasons, including poor perception of the quality and availability of gluten-free food products compared with gluten-containing comparisons, lack of support, dietary education and information, and poor understanding of food labels (Pietzak, 2005).

Common reasons for persisting symptoms are lactose intolerance, pancreatic insufficiency and microscopic colitis. However, persistent symptoms are usually the result of inadvertent ingestion of gluten (Ahmad et al. 2002), which contaminates many products in the food chain (Ciacci \& Mazzacca, 1998; Collin et al. 2004; Thompson, 2005).

\section{Referral to a state-registered dietitian}

Referral to a state-registered dietitian is essential in order to adopt a problem-solving approach with on-going review and support in the management of $C D$ and any associated conditions or secondary problems (Anderson, 2005). Dietetic intervention needs to be based on individual assessment of nutritional requirements, but is also dependent on socio-economic and cultural factors (Bardella et al. 1994). The British Society of Gastroenterology (2002) guidelines on the management of $\mathrm{CD}$ recommend that patients should be seen by a dietitian 
at diagnosis and then at regular intervals in order to provide dietary education and assess nutritional status. In patients with a satisfactory response to the GFD there should be a minimum of six-monthly dietetic review. On-going support by the healthcare team, including the general practitioner, gastroenterologist, dietitian, pharmacist and practice nurse, is essential. Children require specific monitoring of growth and development and nutritional requirements, and a paediatric gastroenterologist and paediatric dietitian should be involved.

Dietary intervention needs to take into account increased requirements for $\mathrm{Ca}$ and advice to promote good bone health. Achieving the recommended intake of $\mathrm{Ca}$ for adults of $1.5 \mathrm{~g} / \mathrm{d}$ (Scott et al. 2000) in patients with CD with low bone density or osteoporosis requires assessment, support and on-going advice. Long-term maintenance of the GFD is pivotal in optimising absorption.

Although other dietary deficiencies, including $\mathrm{Fe}$ deficiency resulting in anaemia, may resolve over a period of time once the patient follows a GFD, it seems reasonable to ensure rapid correction with appropriate supplements. Patients need individual advice on appropriate supplementation in the management of CD (British Society of Gastroenterology, 2002).

Individuals with $\mathrm{CD}$ may also require dietetic intervention for weight management, management of cardiovascular risk factors and other possible concomitant conditions. Patients may also have additional dietary considerations such as lactose intolerance, diabetes and hypercholesterolaemia. Solving individual problems requires on-going review and monitoring, and needs to be based on medical and dietary history.

Trouble-shooting and consideration of the elimination of ingredients that contain a low level of gluten within the Codex standard (Codex Alimentarius Commission, 1981, 1983), including Codex wheat starch, malt extract (used particularly in breakfast cereals) and oats, may be necessary in the dietetic management of patients with $\mathrm{CD}$. An individualised approach is essential.

Although management of patients with CD in the UK is not always consistent with the British Society of Gastroenterology (2002) recommendations for regular review, dietitian-led coeliac clinics are evolving as a way forward, using healthcare resources most effectively and improving care of patients with CD (Wylie et al. 2005).

\section{Gluten-free standard}

On-going problems may also arise because individuals do not maintain a low-enough gluten intake. This situation arises because foods can be labelled 'gluten-free' as long as they have a level of gluten $<200 \mathrm{mg} / \mathrm{kg}$, the internationally-accepted Codex standard that is applied in many parts of Europe, including the UK (Codex Alimentarius Commission, 2004a,b). In practice, the Codex standard was developed in line with the introduction of gluten-free breads and flour mixes containing Codex wheat starch. These products have improved quality and compliance on the GFD (Collin et al. 2004). A Finnish group have reported a safe and practical threshold of $100 \mu \mathrm{g}$ gluten $/ \mathrm{g}$, providing that the total daily intake does not exceed $300 \mathrm{~g}$ wheat-starch-based gluten-free flour (Collin et al. 2004).

The Codex standard also relates to a method of detection of gluten in foods (Food and Agriculture Organization/World Health Organization, 2003). Further work is being carried out to refine the methodology to assess the gluten content of foods (Valdes et al. 2003). There is a global debate about the gluten standard as the Codex Committee on Nutrition and Foods for Special Dietary Uses awaits further scientific evidence to support a threshold or tolerance level. Studies indicate that Codex wheat-starch products are safe for the majority of patients with CD (Ciclitira et al. 1984, 1985; Kaukinen et al. 1999), but there have been studies that indicate that some individuals continue to have symptoms on these products (Biagi et al. 2004), which resolve when the products are discontinued (Chartrand et al. 1997; Faulkner-Hogg et al. 1999; Peraaho et al. 2003). One of the issues relating to the Codex standard and the inclusion of Codex wheat-starch products, or other products such as malted breakfast cereals or oats, that may contain low levels of gluten is recognition that there is an additive effect of eating a low level of gluten and there are considerable differences between individuals with $\mathrm{CD}$ in their response to gluten ingestion (Ciclitira et al. 2005).

\section{Food labelling}

Education on the GFD requires continuing information on food labelling in order for patients with CD to understand food labels and be able to identify gluten-free foods. Dietary education needs to take into account developments in food labelling. A new EU labelling Directive 2003/89/ EC (European Commission, 2003), which provides guidelines for the food industry on labelling of allergens in food products was published on 25 November 2003 and will be obligatory by 25 November 2005. This new guidance will help patients with $\mathrm{CD}$ to identify gluten in food products. All ingredients will be listed and any allergen present highlighted as 'contains gluten' or 'contains wheat' (European Commission, 2000).

\section{Gluten-free foods}

There are different ranges of specialist gluten-free foods, e.g. bread and pasta, to replace standard wheat-containing varieties. Some of these foods can be obtained on prescription, from health-food shops, mail order, pharmacies, the internet and supermarkets, with some big retailers producing their own ranges of gluten-free foods. The availability of gluten-free foods on prescription can aid compliance with the GFD (Collin et al. 2004).

\section{Gluten-free foods on prescription}

Gluten-free foods available on prescription tend to be staples such as bread, flour, bread and cake mixes, pizzas, crackers and pasta. Patients may need to obtain samples of products from manufacturers in order to understand exactly which products they require on prescription on a regular 
basis. The local dietitian can provide specific guidance on products and manufacturers.

The gluten-free foods that are available on prescription are listed in the National Health Service Drug Tariff for England and Wales, which is compiled on behalf of the Department of Health by the Prescription Pricing Authority (Drug Tariff, Part XV; Prescription Pricing Authority, 2005) and agreed by the Advisory Committee on Borderline Substances. Patients with CD still have to pay for prescriptions, unless they meet the criteria for exemption, i.e. children, full-time education, the elderly or those individuals on income support or other benefits.

There are new guidelines available to healthcare professionals on reasonable quantities of gluten-free foods for individual patients, based on nutritional requirements (Good Relations Healthcare, 2004). Gluten-free food products have been allocated unit values and there are suggestions relating to the number of units that should be allocated on a regular monthly basis to individuals based on age and gender.

\section{Coeliac UK's Food and Drink Directory}

Coeliac UK (High Wycombe, Bucks., UK) produces a range of resources that provide information on $\mathrm{CD}$ and the GFD. Processed foods are limited as they may contain added thickeners, flavourings and anti-caking agents, which may be derived from wheat. One such resource is the Food and Drink Directory (Coeliac UK, 2005a), which is updated on a monthly basis (Coeliac UK, 2005b) and lists $>11000$ foods that are gluten-free, including baby foods, foods available on prescription, bulk-catering products and processed foods.

\section{Conclusion}

$\mathrm{CD}$, one of the commonest inherited disorders, can manifest itself in many ways and at all ages. Although an autoimmune condition, it is unique in being entirely curable by diet. However, complete avoidance of gluten is a real challenge for individuals with $\mathrm{CD}$, as 'gluten-free' cereal products are allowed to contain $\leq 200 \mu \mathrm{g}$ gluten $/ \mathrm{g}$, and there is evidence of widespread contamination of many naturally gluten-free foods with wheat. In addition, current market trends show that consumers are eating more processed foods, in which wheat is commonly used as an ingredient. Clear labelling, education and awareness are key issues.

Important questions about $\mathrm{CD}$ remain unanswered, including the nature of the genetic abnormality, the precise mechanism of damage to the gut mucosa, the reasons for so many systems of the body to be involved, the association with other conditions such as type 1 diabetes and tolerance levels of gluten in individuals. Further evidence is awaited that will provide a more accurate picture of the impact of low levels of gluten ingestion and facilitate a more definitive line on the gluten standard as defined by the Codex Alimentarius Commission $(2004 a, b)$. CD is now firmly on the agenda, 50 years after the first gut biopsies were done.

\section{References}

Abdulkarim AS \& Murray JA (2003) Review article: the diagnosis of coeliac disease. Alimentary Pharmacology and Therapeutics 17, 987-995.

Addolorato G, Capristo E, Ghittoni G, Valeri C, Masciana R, Ancona C \& Gasbarrini G (2001) Anxiety but not depression decreases in coeliac patients after one-year gluten-free diet: A longitudinal study. Scandinavian Journal of Gastroenterology 36, 502-506.

Ahmad S, Abdulkarim MD, Lawrence J, Burgart MD, Jacalyn AJ \& Murray MD (2002) Etiology of nonresponsive celiac disease: results of a systematic approach. American Journal of Gastroenterology 97, 2016-2021.

Alaedini A \& Green PHR (2005) Narrative review: Celiac disease: Understanding a complex autoimmune disorder. Annals of Internal Medicine 142, 289-298.

Anderson RP (2005) Coeliac disease. Australian Family Physician 34, 239-242.

Anderson RP, Degano P, Godkin AJ, Jewell DP \& Hill AVS (2000) In vivo antigen challenge in coeliac disease identifies a single transglutaminase-modified peptide as the dominant A-gliadin T-cell epitope. Nature Medicine 6, 337-342.

Arato A, Korner A, Veres G, Dezsofi A, Ujpal I \& Madacsy L (2003) Frequency of coeliac disease in Hungarian children with type 1 diabetes mellitus. European Journal of Pediatrics 162, $1-5$.

Ascher H, Krantz I, Rydberg L, Nordin P \& Kristiansson B (1997) Influence of infant feeding and gluten intake on coeliac disease. Archives of Disease in Childhood 76, 113-117.

Ashabani A, Abushofa U, Abusrewill S, Abdelazez M, Tuckova L \& Tlaskalova-Hogenova H (2003) The prevalence of coeliac disease in Libyan children with type 1 diabetes mellitus. Diabetes/Metabolism Research and Reviews 19, 69-75.

Askling J, Linet M, Gridley G \& Halstensen TS (2002) Cancer incidence in a population-based cohort of individuals hospitalized with celiac disease or dermatitis herpetiformis. Gastroenterology 123, 1428-1435.

Auricchio S, Troncone R \& Maurano F (1999) Coeliac disease in the year 2000. Italian Journal of Gastroenterology and Hepatology 31, 773-780.

Austin AS, Logan RFA, Thomason K \& Holmes GKT (2002) Cigarette smoking and adult coeliac disease. Scandinavian Journal of Gastroenterology 37, 978-982.

Bardella MT, Fredella C, Prampolini L, Molteni N, Giunta AM \& Bianchi PA (2000) Body composition and dietary intakes in adult celiac disease patients consuming a strict gluten-free diet. American Journal of Clinical Nutrition 72, 937-939.

Bardella MT, Molteni N, Prampolini L, Giunta AM, Baldassarri AR, Morganti D \& Bianchi PA (1994) Need for follow-up in celiac-disease. Archives of Disease in Childhood 70, 211-213.

Bardella MT, Valenti L, Pagliari C, Peracchi M, Fare M, Fracanzani AL \& Fargion S (2004) Searching for coeliac disease in patients with non-alcoholic fatty liver disease. Digestive and Liver Disease 36, 333-336.

Bazzigaluppi E, Lampasona V, Barera G, Venerando A, Bianchi C, Chiumello G, Bonifacio E \& Bosi E (1999) Comparison of tissue transglutaminase-specific antibody assays with established antibody measurements for coeliac disease. Journal of Autoimmunity 12, 51-56.

Bennet TI, Hunter D \& Vaughan JM (1932) Idiopathic steatorrhea (Gee's disease). A nutritional disturbance associated with tetany, osteomalacia and anemia. Quarterly Journal of Medicine 1, 603-677.

Berger R \& Schmidt G (1996) Evaluation of six antigliadin antibody assays. Journal of Immunological Methods 91, 77-86. 
Biagi F, Campanella J, Martucci S, Pezzimenti D, Ciclitira PJ, Ellis, HJ \& Corazza GR (2004) A milligram of gluten a day keeps the mucosal recovery away: A case report. Nutrition Reviews 6, 360-363.

Biagi F, Ellis HJ, Parnell NDJ, Shidrawi RG, Thomas PD, O'Reilly N, Corazza GR \& Ciclitira PJ (1999) A non-toxic analogue of a coeliac-activating gliadin peptide: a basis for immunomodulation? Alimentary Pharmacology and Therapeutics 13, 945-950.

Bingley PJ, Williams AJK, Norcross AJ, Unsworth DJ, Lock RJ, Ness AR \& Jones RW (2004) Undiagnosed coeliac disease at age seven: population based prospective birth cohort study. British Medical Journal 328, 322-323.

Bottaro G, Cataldo F, Rotolo N, Spina M \& Corazza GR (1999) The clinical pattern of subclinical silent celiac disease: An analysis on 1026 consecutive cases. American Journal of Gastroenterology 94, 691-696.

British Dietetic Association (2005) Paediatric Group Position Statement on breastfeeding and weaning on to solid foods. Dietetics Today 40(3), 7.

British Society of Gastroenterology (2002) Guidelines for the management of patients with coeliac disease. http:// www.bsg.org.uk/clinical_prac/guidelines.htm.

Burgin-Wolff A, Dahlbom I, Hadziselimovic F \& Petersson CJ (2002) Antibodies against human tissue transglutaminase and endomysium in diagnosing and monitoring coeliac disease. Scandinavian Journal of Gastroenterology 37, 685-691.

Butcher GP, Banks LM \& Walters JRF (1992) Reduced bone mineral density in coeliac disease - the need for bone densitometry estimations. Gut 33, S54.

Caraceni MP, Molteni N, Bardella MT, Ortolani S, Nogara A \& Bianchi PA (1988) Bone and mineral metabolism in adult celiac disease. American Journal of Gastrenterology 83, 274-277.

Card TR, West J \& Holmes GK (2004) Risk of malignancy in diagnosed coeliac disease: a 24 -year prospective, populationbased, cohort study. Alimentary Pharmacology and Therapeutics 20, 769-775.

Case S (2005) The gluten-free diet: How to provide effective education and resources. Gastroenterology 128, S128-S134.

Castano L, Ortiz L, Blarduni E, Nunez J, Bilbao J, Rica I, Martul P \& Vitoria JC (2003) Three-year follow-up of healthy newborns for celiac disease diagnosis. Journal of Pediatric Gastroenterology and Nutrition 36, 536.

Cataldo F, Bottaro G, Magazzu G, Distefano P, Paternostro D, Rotolo N, Spina M, Traverso G \& Violante M (1995) Influence of infant-feeding practices in the first year of life on celiacdisease - results of a Sicilian collaborative study. Rivista Italiana di Pediatria-Italian Journal of Pediatrics 21, 185-190.

Cataldo F, Lio D, Marino V, Picarelli A, Ventura A \& Corazza GR (2000) IgG(1) antiendomysium and IgG antitissue transglutaminase (anti-tTG) antibodies in coeliac patients with selective IgG deficiency. Gut 47, 366-369.

Catassi C, Fabiani E, Corrao G, Barbato M, De Renzo A, Carella AM et al. (2002) Risk of non-Hodgkin lymphoma in celiac disease. Journal of the American Medical Association 287, 1413-1419.

Cellier C, Flobert C, Cormier C, Roux C \& Schmitz J (2000) Severe osteopenia in symptom-free adults with a childhood diagnosis of coeliac disease. Lancet 355, 806.

Chartrand LJ, Augulnik J, Vanounou T, Russo PA, Baehler P \& Seidman EG (1997) Effectiveness of antigliadin antibodies as a screening test for celiac disease in children. Canadian Medical Association Journal 157, 527-533.

Ch'ng CL, Biswas M, Benton A, Jones MK \& Kingham JGC (2005) Prospective screening for coeliac disease in patients with Graves' hyperthyroidism using anti-gliadin and tissue transglutaminase antibodies. Clinical Endocrinology $\mathbf{6 6}$, 303-306.

Chorzelski TP, Beutner EH, Sulej J, Tchorzewska H, Jablonska S, Kumar V \& Kapuscinska A (1984) IgA anti-endomysium antibody - a new immunological marker of dermatitis herpetiformis and coeliac disease. British Journal of Dermatology 111, 395-402.

Ciacci C, Cavallardo R, della Valle N \& d'Argenio G (2002) The use of serum tTG-ab assay in patients on gluten-free diet as a measure of dietetic compliance. Gastroenterology 122, 588.

Ciacci C, Cirillo M, Auriemma G, DiDato G, Sabbatini F \& Mazzacca G (1996) Celiac disease and pregnancy outcome. American Journal of Gastroenterology 91, 718-722.

Ciacci C, Iovino P, Amoruso D, Siniscalchi M, Tortora R, Di Gilio A, Fusco M \& Mazzacca G (2005) Grown-up coeliac children: the effects of only a few years on a gluten-free diet in childhood. Alimentary Pharmacology and Therapeutics 21, 421-429.

Ciacci C \& Mazzacca G (1998) Unintentional gluten ingestion in celiac patients. Gastroenterology 155, 243-250.

Ciclitira PJ (2001) AGA technical review on celiac sprue. Gastroenterology 120, 1526-1540.

Ciclitira PJ, Cerio R, Ellis HJ, Maxton D, Nelufer JM \& Macartney JM (1985) Evaluation of a gliadin containing gluten-free product in coeliac patients. Human Nutrition Clinical Nutrition 39, 303-308.

Ciclitira PJ, Ellis HJ \& Fagg NL (1984) Evaluation of a glutenfree product containing wheat gliadin in patients with coeliac disease. British Medical Journal 289, 83.

Ciclitira PJ, Ellis HJ \& Lundin KE (2005) Gluten-free diet - what is toxic? Best Practice and Research in Clinical Gastroenterology 19, 359-371.

Codex Alimentarius Commission (1981) Codex Standard for 'Gluten-Free Foods'. Codex stan 118-1981. http://www. codexalimentarius.net/download/standards/291/CXS 118e.pdf

Codex Alimentarius Commission (1983) Codex Standard for 'Gluten-Free Foods'. Codex stan 118-1981 (amended 1983). ftp://ftp.fao.org/codex/standard/en/CXS_118e.pdf

Codex Alimentarius Commission (2004a) Report of the 25th Session of the Codex Committee on Nutrition and Foods for Special Dietary Uses. ALINORM 03/27/26. Appendix III Revised Draft Standard for Gluten-Free Foods. pp. 42-43. Rome: FAO.

Codex Alimentarius Commission (2004b) Report of the 26th Session of the Codex Committee on Nutrition and Foods for Special Dietary Uses. ALINORM 05/28/26. para 5-7. pp. 117-118. Rome: FAO.

Coeliac UK (2005a) Coeliac UK's Food and Drink Directory. Your Essential Guide to Gluten-free Food. High Wycombe, Bucks.: Coeliac UK

Coeliac UK (2005b) Food and Drink Directory monthly updates. http://www.coeliac.co.uk/

Collin P, Reunala T, Pukkala E, Laippala P, Keyrilainen O \& Pasternack A (1994) Coeliac disease - associated disorders and survival. Gut 35, 1215-1218.

Collin P, Thorell L, Kaukinen K \& Maki M (2004) The safe threshold for gluten contamination in gluten-free products. Can trace amounts be accepted in the treatment of coeliac disease? Alimentary Pharmacology and Therapeutics 19, 1277-1283.

Corazza GR, Andreani ML, Biagi F, Corrao G, Pretolani S, Giulianelli G, Ghironzi G \& Gasbarrini G (1997) The smaller size of the 'coeliac iceberg' in adults. Scandinavian Journal of Gastroenterology 32, 917-919.

Corazza GR, Di Sario A, Cecchetti L, Jorizzo RA, Di Stefano M, Minguzzi L, Brusco G, Bernardi M \& Gasbarrini A (1996) Influence of pattern of clinical presentation and of gluten-free 
diet on bone mass and metabolism in adult coeliac disease. Bone 18, 525-530.

Corazza GR, Di Sario A, Cecchetti L, Tarozzi C, Corrao G, Bernardi M \& Gasbarrini G (1995) Bone mass and metabolism in patients with celiac disease. Gastroenterology 109, 122-128.

Corrao G, Corazza GR, Bagnardi V, Brusco G, Ciacci C, Cottone M et al. (2001) Mortality in patients with coeliac disease and their relatives: a cohort study. Lancet 358, 356-361.

Csizmadia CGDS, Mearin ML, von Blomberg MBE, Brand R \& Verloove-Vanhorick SP (1999) An iceberg of childhood coeliac disease in the Netherlands. Lancet 353, 813-814.

D'Amico MA, Stavropoulos SN, Frederick M, Levy J, Holmes J, Defelice AR \& Green PHR (2003) The effect of breastfeeding on pediatric celiac disease in the USA. Gastroenterology 124, A-516.

Dahele A \& Ghosh S (2000) The role of serological tests in redefining coeliac disease. Proceedings of the Royal College of Physicians of Edinburgh 30, 100-113.

Department of Health (1994) Weaning and the Weaning Diet. Report on Health and Social Subjects no. 45. London: H. M. Stationery Office.

Department of Health (1995) Sensible drinking. The report of an Inter-departmental Working Group. http://www.dh.gov.uk/ assetRoot/04/08/47/02/04084702.pdf

Department of Health (1996) While You are Pregnant How to Avoid Infection from Food and from Contact with Animals. London: Department of Health.

Department of Health (2000) Folic acid and the Prevention of Disease. Report on Health and Social Subjects no. 50, London: H. M. Stationery Office.

Dickey W, Hughes DF \& McMillan SA (2000a) Reliance on serum endomysial antibody testing underestimates the true prevalence of coeliac disease by one fifth. Scandinavian Journal of Gastroenterology 35, 181-183.

Dickey W, Hughes DF \& McMillan SA (2000b) Disappearance of endomysial antibodies in treated celiac disease does not indicate histological recovery. American Journal of Gastroenterology 95, 712-714.

Dieterich W, Ehnis T, Bauer M, Donner P, Volta U, Riecken EO \& Schuppan D (1997) Identification of tissue transglutaminase as the autoantigen of celiac disease. Nature Medicine $\mathbf{3}$, 797-801.

Diosdado B, Wapenaar MC, Franke L, Duran KJ, Goerres MJ, Hadithi M et al. (2004) A microarray screen for novel candidate genes in coeliac disease pathogenesis. Gut 53, 944-951.

Di Stefano M, Jorizzo RA, Veneto G, Cecchetti L, Gasbarrini G \& Corazza GR (1999) Bone mass and metabolism in dermatitis herpetiformis. Digestive Diseases and Sciences 44, 2139-2143.

Dube C, Rostom A, Sy R, Cranney A, Saloojee N, Garritty C et al. (2005) The prevalence of celiac disease in average-risk and at-risk Western European populations: a systematic review. Gastroenterology 128, S57-S67.

Duggan JM \& Duggan AE (2005) Systematic review: the liver in coeliac disease. Alimentary Pharmacology and Therapeutics 21, 515-518.

Elsurer R, Tatar G, Simsek H, Balaban YH, Aydinli M \& Sokmensuer C (2005) Celiac disease in the Turkish population. Digestive Diseases and Sciences 50, 136-142.

European Commission (2000) Directive 2000/13/EC of the European Parliament and of the Council of 20 March 2000 on the approximation of the laws of the Member States relating to the labelling, presentation and advertising of foodstuffs. Official Journal of the European Union L109, 29-42.

European Commission (2003) Directive 2003/89/EC of the European Parliament and of the Council of 10 November 2003 amending Directive200/13/EC as regards indication of the ingredients present in foodstuffs. Official Journal of the European Union L308, 15-18.

Fabiani E, Peruzzi E, Mandolesi A, Garbuglia G, Fanciulli G, D’Appello AR, Gasparin M, Bravi E, Bearzi I, Galeazzi R \& Catassi C (2004) Anti-human versus anti-guinea pig tissue transglutaminase antibodies as the first-level serological screening test for coeliac disease in the general population. Digestive and Liver Disease 36, 671-676.

Fabiani E, Taccari LM, Ratsch IM, Di Giuseppe S, Coppa GV \& Catassi C (2000) Compliance with gluten-free diet in adolescents with screening-detected celiac disease: A 5-year followup study. Journal of Pediatrics 136, 841-843.

Fasano A, Berti I, Gerarduzzi T, Not T, Colletti RB, Drago S et al. (2003) Prevalence of celiac disease in at-risk and notat-risk groups in the United States - a large multicenter study. Archives of Internal Medicine 163, 286-292.

Faulkner-Hogg KB, Selby WS \& Loblay RH (1999) Dietary analysis in symptomatic patients with coeliac disease on a gluten-free diet: the role of trace amounts of gluten and nongluten food intolerances. Gastroenterology 34, 784-789.

Feighery C (1999) Coeliac disease. British Medical Journal 319 236-239.

Floreani A, Betterle C, Baragiotta A, Martini S, Venturi C, Basso D, Pittoni M, Chiarelli S \& Guidetti CS (2002) Prevalence of coeliac disease in primary biliary cirrhosis and of antimitochondrial antibodies in adult coeliac disease patients in Italy. Digestive and Liver Disease 34, 258-261.

Food and Agriculture Organization/World Health Organization (2003) Draft revised standard for gluten-free foods. Report of the twenty-fifth session of the Codex Committee on Nutrition and Foods for Special Dietary Uses, paragraphs 9 and 10. ftp:// ftp.fao.org/docrep/fao/meeting/008/j1464e.pdf

Food Standards Agency (2002) Feeding your Baby. From Breastfeeding to Solid Foods. London: The Stationery Office.

Fraser JS, Engel W, Ellis HJ, Pollock EL, Wieser H \& Ciclitira PJ (2003) Coeliac disease: in vivo toxicity of the putative immunodominant epitope. Gut 52, 1698-1702.

Gandolfi L, Pratesi R, Cordoba JCM, Tauil PL, Gasparin M \& Catassi C (2000) Prevalence of celiac disease among blood donors in Brazil. American Journal of Gastroenterology 95, 689-692.

Gillett H, Drummond H, Goddard C, Shand A \& Satsangi J (2003) Complications of coeliac disease - how common and can they be prevented? Gut 52, A10.

Gillett HR \& Freeman HJ (2000a) Comparison of IgA endomysium antibody and IgA tissue transglutaminase antibody in celiac disease. Canadian Journal of Gastroenterology 14, 668-671.

Gillett HR \& Freeman HJ (2000b) Prevalence of celiac disease in collagenous and lymphocytic colitis. Canadian Journal of Gastroenterology 14, 919-921.

Gillett PM, Gillett HR, Israel DM, Metzger DL, Stewart L, Chanoine JP \& Freeman HJ (2000) Increased prevalence of celiac disease in girls with Turner syndrome detected using antibodies to endomysium and tissue transglutaminase. Canadian Journal of Gastroenterology 14, 915-918.

Gillett PM, Gillett HR, Israel DM, Metzger DL, Stewart L, Chanoine JP \& Freeman HJ (2001) High prevalence of a celiac disease in patients with type 1 diabetes detected by antibodies to endomysium and tissue transglutaminase. Canadian Journal of Gastroenterology 15, 297-301.

Goldacre MJ, Wotton CJ, Seagroatt V \& Yeates D (2004) Cancers and immune related diseases associated with Down's syndrome: a record linkage study. Archives of Disease in Childhood 89, 1014-1017.

Gomez JC, Selvaggio GS, Viola M, Pizarro B, la Motta G, de Barrio S et al. (2001) Prevalence of celiac disease in 
Argentina: Screening of an adult population in the La Planta area. American Journal of Gastroenterology 96, 2700-2704.

Good Relations Healthcare (2004) Gluten-free Foods: A Prescribing Guide. London: Good Relations Healthcare.

Gough KR, Read AE \& Naish JM (1962) Intestinal reticulosis as a complication of idiopathic steatorrhoea. Gut 3, 232-239.

Greco L, Romino R, Coto I, Di Cosmo N, Percopo S, Maglio M et al. (2002) The first large population based twin study of coeliac disease. Gut 50, 624-628.

Greco L, Veneziano A, Di Donato L, Zampella C, Pecoraro M, Paladini D, Paparo F, Vollaro A \& Martinelli P (2004) Undiagnosed coeliac disease does not appear to be associated with unfavourable outcome of pregnancy. Gut 53, 149-151.

Green PHR, Fleischauer AT, Bhagat G, Goyal R, Jabri B \& Neugut AI (2003) Risk of malignancy in patients with celiac disease. American Journal of Medicine 115, 191-195.

Green PHR \& Jabri B (2003) Coeliac disease. Lancet 362 , 383-392.

Green PHR, Stavropoulos SN, Panagi SG, Goldstein SL, McMahon DJ, Absan H \& Neugut AI (2001) Characteristics of adult celiac disease in the USA: results of a national survey. American Journal of Gastroenterology 96, 126-131.

Habior A, Lewartowska A, Orlowska J, Zych W, Sandowska M, Bauer A \& Butruk E (2003) Association of coeliac disease with primary biliary cirrhosis in Poland. European Journal of Gastroenterology and Hepatology 15, 159-164.

Hallert C, Grant C, Grehn S, Granno C, Hulten S, Midhagen G, Strom M, Svensson H \& Valdimarsson T (2002) Evidence of poor vitamin status in coeliac patients on a gluten-free diet for 10 years. Alimentary Pharmacology and Therapeutics 16, $1333-1339$

Hansen D, Bennedbaek FN, Hansen LK, Hoier-Madsen M, Hegedus L, Jacobsen B \& Husby S (2001) High prevalence of coeliac disease in Danish children with type I diabetes mellitus. Acta Paediatrica 90, 1238-1243.

Henderson L, Irving K, Gregory J, Bates CJ, Prentice A, Perks J, Swan G \& Farron M (2003) The National Diet and Nutrition Survey: Adults Aged 19 to 64 Years. vol. 3: Vitamin and Mineral Intake and Urinary Analytes. London: The Stationery Office.

Hervonen K, Viljamaa M, Collin P, Knip M \& Reunala T (2004) The occurrence of type 1 diabetes in patients with dermatitis herpetiformis and their first-degree relatives. British Journal of Dermatology 150, 136-138.

Hervonen K, Vornanen M, Kautiainen H, Collin P \& Reunala T (2005) Lymphoma in patients with dermatitis herpetiformis and their first-degree relatives. British Journal of Dermatology 152, 82-86.

Hill ID, Dirks MH, Liptak GS, Colletti RB, Fasano A, Guandalini S, Hoffenberg EJ, Horvarth K, Murray JA, Pivor M \& Seidman EG (2005) Guidelines for the diagnosis and treatment of celiac disease in children: Recommendations of the North American Society for Pediatric Gastroenterology, Hepatology and Nutrition. Journal of Pediatric Gastroenterology and Nutrition 40, 1-19.

Hill PG, Semeraro D \& Holmes GKT (2004) IgA antibodies to human tissue transglutaminase: Audit of routine practice confirms high diagnostic accuracy. Scandinavian Journal of Gastroenterology 39, 1078-1082.

Hin H, Bird G, Fisher P, Mahy N \& Jewell D (1999) Coeliac disease in primary care: case finding study. British Medical Journal 318, 164-167.

Hogberg L, Laurin P, Falth-Magnusson K, Grant C, Grodzinsky E, Jansson G et al. (2004) Oats to children with newly diagnosed coeliac disease: a randomised double blind study. Gut 53, 649-654.
Holmes GKT, Prior P, Lane MR, Pope D \& Allan RN (1989) Malignancy in coeliac disease - effect of a gluten free diet. Gut 30, 333-338

Hovell CJ, Collett JA, Vautier G, Cheng AJP, Sutanto E, Mallon DF, Olynyk JK \& Cullen DJE (2001) High prevalence of coeliac disease in a population-based study from Western Australia: a case for screening. Medical Journal of Australia 175, 247-250.

Howdle PD, Jalal PK, Holmes GKT \& Houlston RS (2003) Primary small-bowel malignancy in the UK and its association with coeliac disease. QJM: An International Journal of Medicine 96, 345-353.

Ivarsson A, Hernell O, Stenlund H \& Persson LA (2002) Breastfeeding protects against celiac disease. American Journal of Clinical Nutrition 75, 914-921.

Ivarsson A, Persson LA \& Hernell O (2000) Short and long term effects of breast feeding on child health. Advances in Experimental Medicine and Biology 478, 139-149.

James S (editor) (2005) Celiac disease: Proceedings of the NIH Consensus Conference on Celiac Disease. Gastroenterology 128, Suppl. 1, S1-S141.

Janatuinen EK, Kemppainen TA, Julkunen RJK, Kosma V-M, Maki M, Heikkinen M \& Uusitupa MIJ (2002) No harm from five year ingestion of oats in coeliac disease. Gut 50, 332-335.

Jarry B (2003) Coeliac-EU Cluster. http://europa.eu.int/comm/ research/quality-of-life/kal/volume2/qlk1-1999-00037.htm.

Johnston SD, Watson RGP, McMillan SA, Sloan J \& Love AHG (1997) Prevalence of coeliac disease in Northern Ireland. Lancet 350, 1370.

Kaukinen K, Collin P, Holm K, Rantala I, Vuolteenaho N, Renunala T \& Maki M (1999) Wheat starch-containing glutenfree flour products in the treatment of coeliac disease and dermatitis herpetiformis. A long-term follow-up study. Scandinavian Journal of Gastroenterology 34, 163-169.

Kemppainen TA, Kosma V-M, Janatuinen E, Julkunen RJ, Pikkarainen PH \& Uusitupa MIJ (1998) Nutritional status of newly diagnosed celiac disease patients before and after the institution of a celiac disease diet - association with the grade of mucosal villous atrophy. American Journal of Clinical Nutrition 67, 482-487.

Kemppainen TA, Kroger H, Janatuinen E, Arnala I, Kosma VM, Pikkarainen P, Julkunen R, Jurvelin J, Alhava E \& Uusitupa M (1999a) Osteoporosis in adult patients with celiac disease. Bone 24, 249-255.

Kemppainen TA, Kroger H, Janatuinen E, Arnala I, LambergAllardt C, Karkkainen M, Kosma VM, Julkunen R, Jurvelin J, Alhava E \& Uusitupa M (1999b) Bone recovery after a glutenfree diet: A 5-year follow-up study. Bone 25, 355-360.

Kerins DM, Koury MJ, Capdevila A, Rana S \& Wagner C (2001) Plasma S-adenosylhomocysteine is a more sensitive indicator of cardiovascular disease than plasma homocysteine. American Journal of Clinical Nutrition 74, 723-729.

Kluge F, Koch HK, Grossewilde H, Lesch R \& Gerok W (1982) Follow-up of treated adult celiac disease: clinical and morphological studies. Hepatogastroenterology 29, 17-23.

Kolho KL, Farkkila MA \& Savilahti E (1998) Undiagnosed coeliac disease is common in Finnish adults. Scandinavian Journal of Gastroenterology 33, 1280-1283.

Korponay-Szabo IR, Dahlbom I, Laurila K, Koskinen S, Woolley N, Partanen J, Kovacs JB, Maki M \& Hansson T (2003) Elevation of IgG antibodies against tissue transglutaminase as a diagnostic tool for coeliac disease in selective IgA deficiency. Gut 52, 1567-1571.

Kotze LMS (2004) Gynecologic and obstetric findings related to nutritional status and adherence to a gluten-free diet in Brazilian patients with celiac disease. Journal of Clinical Gastroenterology 38, 567-574. 
Kramer MS \& Kakuma R (2002) The Optimal Duration of Exclusive Breastfeeding: A Systematic Review. Rome: WHO; available at http://www.who.int/nut/documents/optimal_dur ation_of_exc_bfeeding_review_eng.pdf

Kumar V, Lerner A, Valeski JE, Beutner EH, Chorzelski TP \& Rossi T (1989) Endomysial antibodies in the diagnosis of celiac-disease and the effect of gluten on antibody-titers. Immunological Investigations 18, 533-544.

Lagerqvist C, Ivarsson A, Juto P, Persson LA \& Hernell O (2001) Screening for adult coeliac disease - which serological marker(s) to use? Journal of Internal Medicine 250, 241-248.

Lawson A, West J, Aithal GP \& Logan RFA (2005) Autoimmune cholestatic liver disease in people with coeliac disease: a population-based study of their association. Alimentary Pharmacology and Therapeutics 21, 401-405.

Lenhardt A, Plebani A, Marcheti F, Gerarduzi T, Not T, Meini A, Villanacci V, Martelossi S \& Ventura A (2004) Role of human-tissue transglutaminase $\mathrm{IgG}$ and anti-gliadin $\mathrm{IgG}$ antibodies in the diagnosis of coeliac disease in patients with selective immunoglobulin A deficiency. Digestive and Liver Disease 36, 730-734.

Lerner A, Kumar V \& Iancu TC (1994) Immunological diagnosis of childhood coeliac disease: comparison between antigliadin, antireticulin and antiendomysial antibodies. Clinical and Experimental Immunology 95, 78-82.

Lo W, Sano K, Lebwohl B, Diamond B \& Green PHR (2003) Changing presentation of adult celiac disease. Digestive Diseases and Sciences 48, 395-398.

Logan RF, Rifkind EA, Turner IE \& Ferguson A (1989) Mortality in celiac disease. Gastroenterology 97, 265-271.

Lundin KEA, Nilsen EM, Scott HG, Loberg EM, Gjoen A, Bratlie J, Skar V, Mendez E, Lovik A \& Kett K (2003) Oats induced villous atrophy in coeliac disease. Gut 52, $1649-1652$.

McFarlane XA, Bhalla AK, Reeves DE, Morgan LM \& Robertson DAF (1995) Osteoporosis in treated adult coeliac disease. Gut 36, 710-714.

Maki M, Mustalahti K, Kokkonen J, Kulmala P, Haapalahti M, Karttunen T et al. (2003) Prevalence of celiac disease among children in Finland. New England Journal of Medicine 348, 2517-2524.

Marsh MN (1992) Gluten, major histocompatibility complex, and the small intestine. Gastroenterology 102, 330-354.

Martin-Villa JM, Lopez-Suarez JC, Perez-Blas M, Martinez-Laso J, Ferre-Lopez S, Garcia-Torre C, Lledo G, Manzanares J \& Arnaiz-Villena A (2001) Coeliac- and enteropathy-associated autoantibodies in Spanish insulin-dependent diabetes mellitus patients and their relation to HLA antigens. Journal of Diabetes and Its Complications 15, 38-43.

Martinelli P, Troncone R, Paparo F, Torre P, Trapanese E, Fasano C, Lamberti A, Budillon G, Nardone G \& Greco L (2000) Coeliac disease and unfavourable outcome of pregnancy. Gut 46, 332-335.

Mason JB (2002) Diet, folate, and colon cancer. Current Opinion in Gastroenterology 18, 229-234.

Matysiak-Budnik T, Candalh C, Dugave C, Namane A, Cellier C, Cerf-Bensussan N \& Heyman M (2003) Alterations of the intestinal transport and processing of gliadin peptides in celiac disease. Gastroenterology 125, 696-707.

Mayer M, Greco L, Troncone R, Auricchio S \& Marsh MN (1991) Compliance of adolescents with celiac-disease with a gluten free diet. Gut 32, 881-885.

Meloni GF, Dessole S, Vargiu N, Tomasi PA \& Musumeci S (1999) The prevalence of coeliac disease in infertility. Human Reproduction 14, 2759-2761.

Meyer D, Stravropolous S, Diamond B, Shane E \& Green PHR (2001) Osteoporosis in a North American adult population with celiac disease. American Journal of Gastroenterology 96, 112-119.

Midhagen G, Aberg AK, Olcen P, Jarnergot G, Valdimarsson T, Dahlbom I, Hansson T \& Strom M (2004) Antibody levels in adult patients with coeliac disease during gluten-free diet: a rapid initial decrease of clinical importance. Journal of Internal Medicine 256, 519-524.

Moreno ML, Vazquez H, Mazure R, Smecuol E, Niveloni S, Pedreira S, Sugai E, Maurino E, Gomez JC \& Bai JC (2004) Stratification of bone fracture risk in patients with celiac disease. Clinical Gastroenterology and Hepatology 2 , 127-134.

Morris AM, Yiannakou JY, King AL, Brett PM, Biagi F, Vaughan R, Curtis D \& Ciclitira PJ (2000) Coeliac disease and Down syndrome: Associations not due to genetic linkage on chromosome 21. Scandinavian Journal of Gastroenterology 35, $177-180$.

Mowat AM (2003) Coeliac disease - a meeting point for genetics, immunology, and protein chemistry. Lancet 361, 1290-1292.

Myhre AG, Aarsetoy H, Undlien DE, Hovdenak N, Aksnes L \& Husebye ES (2003) High frequency of coeliac disease among patients wtih autoimmune adrenocortical failure. Scandinavian Journal of Gastroenterology 38, 511-515.

Norgard B, Fonager K, Sorensen HT \& Olsen J (1999) Birth outcomes of women with celiac disease: A nationwide historical cohort study. American Journal of Gastroenterology $\mathbf{9 4}$ 2435-2440.

Norris JM, Barriga K, Hoffenberg EJ, Taki I, Miao D, Haas JE, Emery LM, Sokol RJ, Erlich HA, Eisenbarth GS \& Rewers M (2005) Risk of celiac disease autoimmunity and timing of gluten introduction in the diet of infants at increased risk of disease. Journal of the American Medical Association 293, 2342-2351.

Not T, Horvath K, Hill ID, Partanen J, Hammed A, Maguzzu G \& Fasano A (1998) Celiac disease in the USA: High prevalence of antiendomysium antibodies in healthy blood donors. Scandinavian Journal of Gastroenterology 33, 494-498.

Not T, Tommasini A, Tonini G, Buratti E, Pocecco M, Tortul C et al. (2001) Undiagnosed coeliac disease and risk of autoimmune disorders in subjects with Type I diabetes mellitus. Diabetologia 44, 151-155.

O'Leary C, Walsh $\mathrm{CH}$, Wieneke P, O'Regan P, Buckley B, O'Halloran DJ, Ferriss JB, Quigley EMM, Annis P, Shanahan F \& Cronin CC (2002) Coeliac disease and autoimmune Addison's disease: a clinical pitfall. QJM: Monthly Journal of the Association of Physicians 95, 79-82.

Olesen M, Eriksson S, Bhor J, Jarnerot G \& Tysk C (2004) Lymphocytic colitis: a retrospective clinical study of 199 Swedish patients. Gut 53, 536-541.

Pazianas M, Butcher GP, Subhani JM, Finch PJ, Ang L, Collins C, Heaney RP, Zaidi M \& Maxwell JD (2005) Calcium absorption and bone mineral density in celiacs after long term treatment with gluten-free diet and adequate calcium intake. Osteoporosis International 16, 56-63.

Peraaho M, Kaukinen K, Paasikivi K, Sievanen H, Lohiniemi S, Maki M \& Collin P (2003) Wheat-starch-based gluten-free products in the treatment of newly detected coeliac disease: prospective and randomized study. Alimentary Pharmacology and Therapeutics 17, 587-594.

Peters U, Askling J, Gridley G, Ekbom A \& Linet M (2003) Causes of death in patients with celiac disease in a populationbased Swedish cohort. Archives of Internal Medicine $\mathbf{1 6 3}$ $1566-1572$.

Peters U, Schneeweiss S, Trautwein EA \& Erbersdobler HF (2001) A case-control study of the effect of infant feeding on celiac disease. Annals of Nutrition and Metabolism 45, 135-142. 
Pietzak MM (2005) Follow-up of patients with celiac disease: Achieving compliance with treatment. Gastroenterology 128, S135-S141.

Pratesi R, Gandolfi L, Garcia SG, Modelli IC, de Almeida PL, Bocca AL \& Catassi C (2003) Prevalence of coeliac disease: Unexplained age-related variation in the same population. Scandinavian Journal of Gastroenterology 38, 747-750.

Prescription Pricing Authority (2005) Drug Tariff Part XV Borderline substances. Gluten-free products. http:// www.ppa.org.uk

Pynnonen PA, Isometsa ET, Aronen ET, Verkasalo MA, Savilahti E \& Aalberg VA (2004) Mental disorders in adolescents with celiac disease. Psychosomatics 45, 325-335.

Pynnonen PA, Isometsa ET, Verkasalo MA, Kahkonen SA, Sipila I, Savilahti E \& Aalberg VA (2005) Gluten-free diet may alleviate depressive and behavioural symptoms in adolescents with coeliac disease: a prospective follow-up caseseries sudy. BMC Psychiatry 5, 14.

Rampertab SD, Forde KA \& Green PHR (2003) Small bowel neoplasia in coeliac disease. Gut 52, 1211-1214.

Rawashdeh MO, Khalil B \& Raweily E (1996) Celiac disease in Arabs. Journal of Pediatric Gastroenterology and Nutrition 23, 415-418.

Reif S \& Lerner A (2004) Tissue transglutaminase - the key player in celiac disease: a review. Autoimmunity Reviews 3, 40-45.

Rostami K, Mulder CJ, van Overbeek FM, Kerckhaert J, Meijer JW, von Blomberg MB \& Heymans HS (2000) Should relatives of coeliacs with mild clinical complaints undergo a small-bowel biopsy despite negative serology? European Journal of Gastroenterology and Hepatology 12, 51-55.

Royal College of Obstetricians and Gynaecologists (1999) Alcohol consumption in pregnancy. http://www.rcog.org.uk/ index.asp?PageID=509

Saadah OI, Zacharin M, O'Callaghan A, Oliver MR \& CattoSmith A (2004) Effect of gluten-free diet and adherence on growth and diabetic control in diabetics with coeliac disease. Archives of Disease in Childhood 89, 871-876.

Sanders DS, Hurlstone DP, McAlindon ME, Hadjivassiliou M, Cross SS, Wild G \& Atkins CJ (2005) Antibody negative coeliac disease presenting in elderly people - an easily missed diagnosis. British Medical Journal 330, 775-776.

Sategna-Guidetti C, Grosso SB, Grosso S, Mengozzi G, Aimo G, Zaccaria T, Di Stefano M \& Isaia GC (2000) The effects of 1 -year gluten withdrawal on bone mass, bone metabolism and nutritional status in newly-diagnosed adult coeliac disease patients. Alimentary Pharmacology and Therapeutics 14, $35-43$.

Saukkonen T, Ilonen J, Akerblom HK \& Savilahti E (2001) Prevalence of coeliac disease in siblings of patients with Type I diabetes is related to the prevalence of of $\mathrm{DQB} 1 * 02$ allele. Diabetologia 44, 1051-1053.

Schweizer JJ, von Blomberg BME, Bueno-de Mesquita HB \& Mearin ML (2004) Coeliac disease in the Netherlands. Scandinavian Journal of Gastroenterology 39, 359-364.

Scott EM, Gaywood I \& Scott BB (2000) Guidelines for osteoporosis in coeliac disease and inflammatory bowel disease. British Society of Gastroenterology. Gut 46, i1-i8.

Shan L, Molberg O, Parrot I, Hausch F, Filiz F, Gray GM, Sollid LM \& Khosla C (2002) Structural basis for gluten intolerance in Celiac sprue. Science 297, 2275-2279.

Skovbjerg H, Hansen GH, Niels-Christiansen LL, Anthonsen D, Ascher H, Midhagen G, Hallert C, Noren O \& Sjostrom H (2004) Intestinal tissue transglutaminase in coeliac disease of children and adults: Ultrastructural localization and variation in expression. Scandinavian Journal of Gastroenterology 39, $1219-1227$.
Smedby KE, Akerman M, Hildebrand H, Glimelius B, Ekbom A \& Askling J (2005) Malignant lymphomas in coeliac disease: evidence of increased risks of lymphoma types other than enteropath-type T cell lymphoma. Gut 54, 54-59.

Sumnik Z, Kolouskova S, Malcova H, Vavrinec J, Venhacova J, Lebl J \& Cinek O (2005) High prevalence of coeliac disease in siblings of children with type 1 diabetes. European Journal of Pediatrics 164, 9-12.

Szodoray P, Barta Z, Lakos G, Szakall S \& Zeher M (2004) Coeliac disease in Sjogren's syndrome - a study of 111 Hungarian patients. Rheumatology International 24, 278-282.

Tata LJ, Card TR, Logan RFA, Hubbard RB, Smith CJP \& West J (2005) Fertility and pregnancy-related events in women with celiac disease: a population-based cohort study. Gastroenterology 128, 849-855.

Tatar G, Elsurer R, Simsek H, Balaban YH, Hascelik G, Ozcebe OI, Buyukasik Y \& Sokmensuer C (2004) Screening of tissue transglutaminase antibody in healthy blood donors for celiac disease screening in the Turkish population. Digestive Diseases and Sciences 49, 1479-1484.

Thomason K, West J, Logan RF, Coupland C \& Holmes GKT (2003) Fracture experience of patients with coeliac disease: a population based survey. Gut 52, 518-522.

Thompson T (1999) Thiamin, riboflavin, and niacin contents of the gluten-free diet: Is there cause for concern? Journal of the American Dietetic Association 99, 858-862.

Thompson T (2000) Folate, iron, and dietary fiber contents of the gluten-free diet. Journal of the American Dietetic Association 100, 1389-1396.

Thompson $\mathrm{T}$ (2005) Contaminated oats and other gluten-free foods in the United States. Journal of the American Dietetic Association 105, 348.

Treem WR (2004) Emerging concepts in celiac disease. Current Opinion in Pediatrics 16, 552-559.

Tursi A, Brandimarte G \& Giorgetti G (2003) Lack of usefulness of anti-transglutaminase antibodies in assessing histologic recovery after gluten-free diet in celiac disease. Journal of Clinical Gastroenterology 37, 387-391.

Tursi A, Giorgetti G, Brandimarte G, Rubino E, Lombardi D \& Gasbarrini G (2001) Prevalence and clinical presentation of subclinical/silent celiac disease in adults: An analysis on a 12-year observation. Hepato-Gastroenterology 48, 462-464.

Vader LW, Stepniak DT, Bunnik EM, Kooy YMC, De Haan W, Drijfhout JW, Van Veelen PA \& Koning F (2003) Characterization of cereal toxicity for celiac disease patients based on protein homology in grains. Gastroenterology 125, 1105-1113.

Vahedi K, Mascart F, Mary JY, Laberenne JE, Bouhnik Y, Morin MC, Ocmant A, Velly C, Colombel JF \& Matuchansky C (2003) Reliability of antitransglutaminase antibodies as predictors of gluten-free diet compliance in adult celiac disease. American Journal of Gastroenterology 98, 1079-1087.

Valdes I, Garcia E, Llorente M \& Mendez E (2003) Innovative approach to low-level gluten determination in foods using a novel sandwich enzyme-linked immunosorbent assay protocol. European Journal of Gastroenterology and Hepatology 15, 465-474.

Valdimarsson T, Franzen L, Grodzinsky E, Skogh T \& Strom M (1996) Is small bowel biopsy necessary in adults with suspected celiac disease and $\operatorname{IgA}$ anti-endomysium antibodies? $100 \%$ positive predictive value for celiac disease in adults. Digestive Diseases and Sciences 41, 83-87.

Valdimarsson T, Toss G, Lofman G \& Strom M (2000) Three years' follow-up of bone density in adult coeliac disease: Significance of secondary hyperparathyroidism. Scandinavian Journal of Gastroenterology 35, 274-280.

Valentino R, Savastano S, Maglio M, Paparo F, Ferrara F, Dorato M, Lombardi G \& Troncone R (2002) Markers of potential 
coeliac disease in patients with Hashimoto's thyroiditis. European Journal of Endocrinology 146, 479-483.

Valerio G, Maiuri L, Troncone R, Buono P, Lombardi F, Palmieri R \& Franzese A (2002) Severe clinical onset of diabetes and increased prevalence of other autoimmune diseases in children with coeliac disease diagnosed before diabetes mellitus. Diabetologia 45, 1719-1722.

Van Belzen MJ, Meijer JWR, Sandkuijl LA, Bardoel AFJ, Mulder CJJ, Pearson PL, Houwen RHJ \& Wijmenga C (2003) A major non-HLA locus in celiac disease maps to chromosome 19. Gastroenterology 125, 1032-1041.

van Odijk J, Hulthen L, Ahlstedt S \& Borres MP (2004) Introduction of food during the infant's first year: a study with emphasis on introduction of gluten and of egg, fish and peanut in allergy-risk families. Acta Paediatrica 93, 464-470.

Vazquez H, Mazure R, Gonzalez D, Flores D, Pedreira S, Niveloni S, Smecuol E, Maurino E \& Bai JC (2000) Risk of fractures in celiac disease patients: A cross-sectional, case-control study. American Journal of Gastroenterology 95, 183-189.

Verkasalo M, Savilahti E, Raitakari O \& Viikari J (2003) Silent coeliac disease - a risk for career? Journal of Pediatric Gastroenterology and Nutrition 36, 535.

Vestergaard P \& Mosekilde L (2002) Fracture risk in patients with celiac disease, Crohn's disease, and ulcerative colitis: A nationwide follow-up study of 16,416 patients in Denmark. American Journal of Epidemiology 156, 1-10.

Wahab PJ, Crusius JB, Meijer JW \& Mulder CJ (2001) Gluten challenge in borderline gluten-sensitive enteropathy. American Journal of Gastroenterology 96, 1464-1469.

Walker-Smith J (1990) Revised criteria for diagnosis of celiac disease: report of working group of European Society of
Pediatric Gastroenterology and Nutrition (ESPAGN). Archives of Disease in Childhood 65, 909-911.

West J, Logan RFA, Card TR, Smith C \& Hubbard R (2003a) Fracture risk in people with celiac disease: A population-based cohort study. Gastroenterology 125, 429-436.

West J, Logan RFA, Card TR, Smith C \& Hubbard R (2004a) Risk of vascular disease in adults with diagnosed coeliac disease: a population-based study. Alimentary Pharmacology and Therapeutics $\mathbf{2 0}, 1-7$.

West J, Logan RFA, Hill PG, Lloyd A, Lewis S, Hubbard R, Reader R \& Holmes GKT (2003b) Seroprevalence, correlates, and characteristics of undetected coeliac disease in England. Gut 52, 960-965.

West J, Logan RFA, Smith CJ, Hubbard RB \& Card TR (2004b) Malignancy and mortality in people with coeliac disease: population based cohort study. British Medical Journal 329, 716-718.

Westman E, Ambler GR, Royle M, Peat J \& Chan A (1999) Children with coeliac disease and insulin dependent diabetes mellitus - growth, diabetes control and dietary intake. Journal of Pediatric Endocrinology and Metabolism 12 433-442.

Whitehead R (1995) Gastrointestinal and Oesophageal Pathology. Hong Kong: Churchill Livingstone.

Whorwell PJ, Alderson MR, Foster KJ \& Wright R (2004) Death from ischaemic heart disease and malignancy in adult patients with coeliac disease. Alimentary Pharmacology and Therapeutics 20, 1-7.

Wylie, C, Geldart S \& Winwood P (2005) Dietitian-led coeliac clinic: a successful change in working practice in modern healthcare. Gastroenterology Today 15, 11-12. 